\title{
Prepartum dietary management of energy intake affects postpartum intake and lactation performance by primiparous and multiparous Holstein cows ${ }^{1}$
}

\author{
N. A. Janovick and J. K. Drackley ${ }^{2}$ \\ Department of Animal Sciences, University of Illinois, Urbana 61801
}

\begin{abstract}
An experiment was conducted to determine the effect of plane of energy intake prepartum on postpartum performance. Primiparous $(\mathrm{n}=24)$ and multiparous $(\mathrm{n}$ = 23) Holsteins were randomly assigned by expected date of parturition to 1 of 3 prepartum energy intakes. A moderate energy diet [1.63 Mcal of net energy for lactation $\left(\mathrm{NE}_{\mathrm{L}}\right) / \mathrm{kg} ; 15 \%$ crude protein $\left.(\mathrm{CP})\right]$ was fed for either ad libitum intake (OVR) or restricted intake (RES) to supply 150 or $80 \%$ of National Research Council (2001) energy requirement, respectively, for dry cows in late gestation. To limit energy intake to $100 \%$ of NRC requirement at ad libitum dry matter intake (DMI), chopped wheat straw was included as $31.8 \%$ of dry matter $(\mathrm{DM})$ in a control diet $(\mathrm{CON} ; 1.21 \mathrm{Mcal}$ of $\mathrm{NE}_{\mathrm{L}} / \mathrm{kg}$ of DM; $14 \% \mathrm{CP}$ ). Multiparous and primiparous cows assigned to OVR gained body condition during the dry period [initial body condition score (BCS) = 3.3], but were not overconditioned by parturition (BCS $=3.5$ ). Multiparous cows in the OVR group lost more BCS postpartum than multiparous RES or CON cows. Primiparous cows lost similar amounts of BCS among dietary treatment groups postpartum. Addition of chopped wheat straw to CON diets prevented a large decrease in DMI prepartum in both primiparous and multiparous cows. During the first 3 wk postpartum, DMI as a percentage of $\mathrm{BW}$ was lower for multiparous OVR cows than for multiparous RES cows. Prepartum diet effects did not carry over through the entire 8-wk lactation period. Because of greater mobilization of body stores, OVR cows had greater milk fat percentage and greater $3.5 \%$ fat-corrected milk yield during the first 3 wk postpartum. Multiparous cows assigned to OVR experienced a $55 \%$ decrease in energy balance and primiparous cows a $40 \%$ decrease in energy balance during the last 3 wk before parturition, compared with
\end{abstract}

\footnotetext{
Received August 18, 2009.

Accepted March 24, 2010.

${ }^{1}$ Supported by State of Illinois and USDA-CSREES regional research funds appropriated to the Illinois Agricultural Experiment Station (projects W-181 and W-1181) and by USDA-CSREES Section 1433 Animal Health and Disease funds.

${ }^{2}$ Corresponding author: drackley@illinois.edu
}

CON or RES cows that had little change. Multiparous cows fed OVR had a greater contribution of energy from body energy reserves to milk energy output than either CON or RES cows. Overfeeding energy prepartum resulted in large changes in periparturient energy balance. Even in the absence of overconditioning, a large change in DMI and energy balance prepartum influenced postpartum DMI and BCS loss, especially for multiparous cows. Chopped wheat straw was effective at controlling energy intake prepartum, although primiparous cows did not achieve predicted DMI. Even so, controlling or restricting energy intake in primiparous cows was not detrimental to lactational performance over the first 8 wk of lactation.

Key words: periparturient cow, energy intake, primiparous cow, multiparous cow

\section{INTRODUCTION}

Limiting intakes of DM and energy prepartum to prevent overconsumption relative to requirements may improve cow health and liver function postpartum (Grum et al., 1996; Rukkwamsuk et al., 1998, 1999; Dann et al., 2006; Douglas et al., 2006). In research settings, it is easy to restrict the amount of feed offered to each cow to control total intake of nutrients. In practical settings with group housing, however, it is more difficult to ensure that all cows in the group are allowed equal amounts of DM when physically restricting the amount of feed provided (Winkelman et al., 2008). A greater inclusion of lower quality forages increases the concentration of NDF in the diet and limits total DMI (NRC, 2001), which at the same time limits total nutrient consumption. Forages such as chopped wheat straw have been successfully used to limit prepartum energy intake (Dann et al., 2006) and improve transition health in the field (Drackley and Dann, 2005; Beever, 2006). Controlled research is needed, however, to elucidate how these diets may compare with physical restriction of intake and ad libitum feeding of a moderate NDF, moderate energy density diet during the dry period.

Data are also needed to answer how controlling energy intake prepartum in primiparous cows may affect their lactational performance. It is not uncommon to 
have multiparous and primiparous cows fed together before parturition, but group feeding raises some important concerns. For example, primiparous cows spend less time at the feed bunk because of their lower social status relative to older cows and, consequently, consume less DM (Grant and Albright, 1995). Restricting energy intake of primiparous cows, whether intentional or not, might be detrimental to milk yield because these cows have requirements for growth in addition to pregnancy and lactation (NRC, 2001). Some studies that have focused on the effect of plane of nutrition on subsequent lactational performance in primiparous cows have indicated that a higher plane of nutrition prepartum may confer advantages over restriction of nutrients prepartum (Broster and Tuck, 1967; Park et al., 1987). In contrast, Lacasse et al. (1993) found no advantage of overfeeding primiparous cows before their first lactation on milk yield or milk components. Prepartum plane of nutrition was not related to productivity or longevity in the herd; rather, reproductive problems were the primary reason cows left the herd (Gardner et al., 1988).

Dry period studies that have included primiparous cows in addition to multiparous cows have not fed diets that have been formulated to truly limit energy intake to NRC (2001) recommendations (VandeHaar et al., 1999; Mashek and Beede, 2001). When diets are not formulated to limit DMI, multiparous cows will overconsume energy relative to requirements (Dann et al., 2006; Douglas et al., 2006), leaving little doubt that the same will hold true for heifers. Diets that can be formulated to control intake when fed ad libitum to mixed groups would allow maximal DMI without allowing overconsumption of energy and other nutrients.

Our hypothesis was that ad libitum feeding of a diet formulated with a greater inclusion of forage NDF would provide adequate nutrients but limit energy intake to NRC (2001) requirements, which would provide benefits similar to those observed with restricted intakes. Therefore, the objectives of this study were to determine the effects of controlling prepartum energy intake in both primiparous and multiparous cows on 1) prepartum feed characteristics including sorting of dietary ingredients, 2) changes in DMI, BW, BCS, and energy balance prepartum and postpartum, and 3) postpartum milk production and milk composition.

\section{MATERIALS AND METHODS}

\section{Animal Management}

All procedures were conducted under protocols approved by the University of Illinois Institutional Animal Care and Use Committee. Both primiparous and mul- tiparous Holstein cows were enrolled in this study. At $72 \mathrm{~d}$ before expected parturition, 24 lactating, multiparous Holstein cows were moved into individual tie stalls and were fed the herd lactation diet at the University of Illinois Dairy Research Unit for ad libitum intake. Cows were dried off $65 \mathrm{~d}$ before expected parturition at which time they were randomly assigned by expected date of parturition to 1 of 3 dry period nutrition treatments (Table 1). For the first dietary treatment group, a moderate energy diet was fed for ad libitum intake (OVR) to provide at least $150 \%$ of NRC (2001) energy requirements $\left(\mathrm{NE}_{\mathrm{L}}\right)$ for dry cows in late gestation. This same diet was fed in restricted amounts (RES) to supply $80 \%$ of $\mathrm{NRC}$ (2001) $\mathrm{NE}_{\mathrm{L}}$ requirements to a second group. For the third group, $\mathrm{NE}_{\mathrm{L}}$ intake was limited to $100 \%$ of NRC (2001) requirement at ad libitum intake using a control (CON) diet. To limit DMI, the CON diet contained chopped wheat straw as $31.8 \%$ of the DM. Cows remained on their respective treatments until parturition; however, a close-up diet, formulated to be similar in nutrient composition to each of the far-off diets but with negative DCAD (Table 1) was fed from $-21 \mathrm{~d}$ to parturition.

At 42 d before expected parturition, 24 primiparous Holstein cows were moved to individual tie stalls and fed the herd dry cow diet at the University of Illinois Dairy Research Unit for ad libitum intake. At $35 \mathrm{~d}$ before expected parturition, these cows were randomly assigned by expected date of parturition to one of the same diets as described for multiparous cows. Primiparous cows remained on their respective treatments through parturition and did not receive the diets altered for DCAD closer to parturition.

From parturition through 60 DIM, both multiparous and primiparous cows consumed a lactation diet (Table 1) balanced to meet or exceed NRC (2001) requirements for cows in early lactation at ad libitum intake. All cows were offered approximately $2.3 \mathrm{~kg}$ of alfalfa hay daily in addition to the TMR from the day of parturition through 10 DIM.

\section{Measurements, Sampling, and Analyses}

Both pre- and postpartum diets were mixed daily and fed as TMR. All cows were individually fed twice daily with approximately half of their daily diet offered at $1100 \mathrm{~h}$ and the remainder at $1700 \mathrm{~h}$. Individual feed offered and feed refusals were recorded daily from the initiation of prepartum treatments through $60 \mathrm{~d}$ postpartum. Cows were housed in tie stalls and were allowed to exercise daily between 0700 and $1000 \mathrm{~h}$ in an outside lot. At $10 \mathrm{~d}$ before expected parturition, cows were moved to individual maternity pens until parturition. After parturition, cows were returned to a 
Table 1. Ingredients and nutrient composition of diets fed to primiparous and multiparous Holstein cows during prepartum and during early lactation

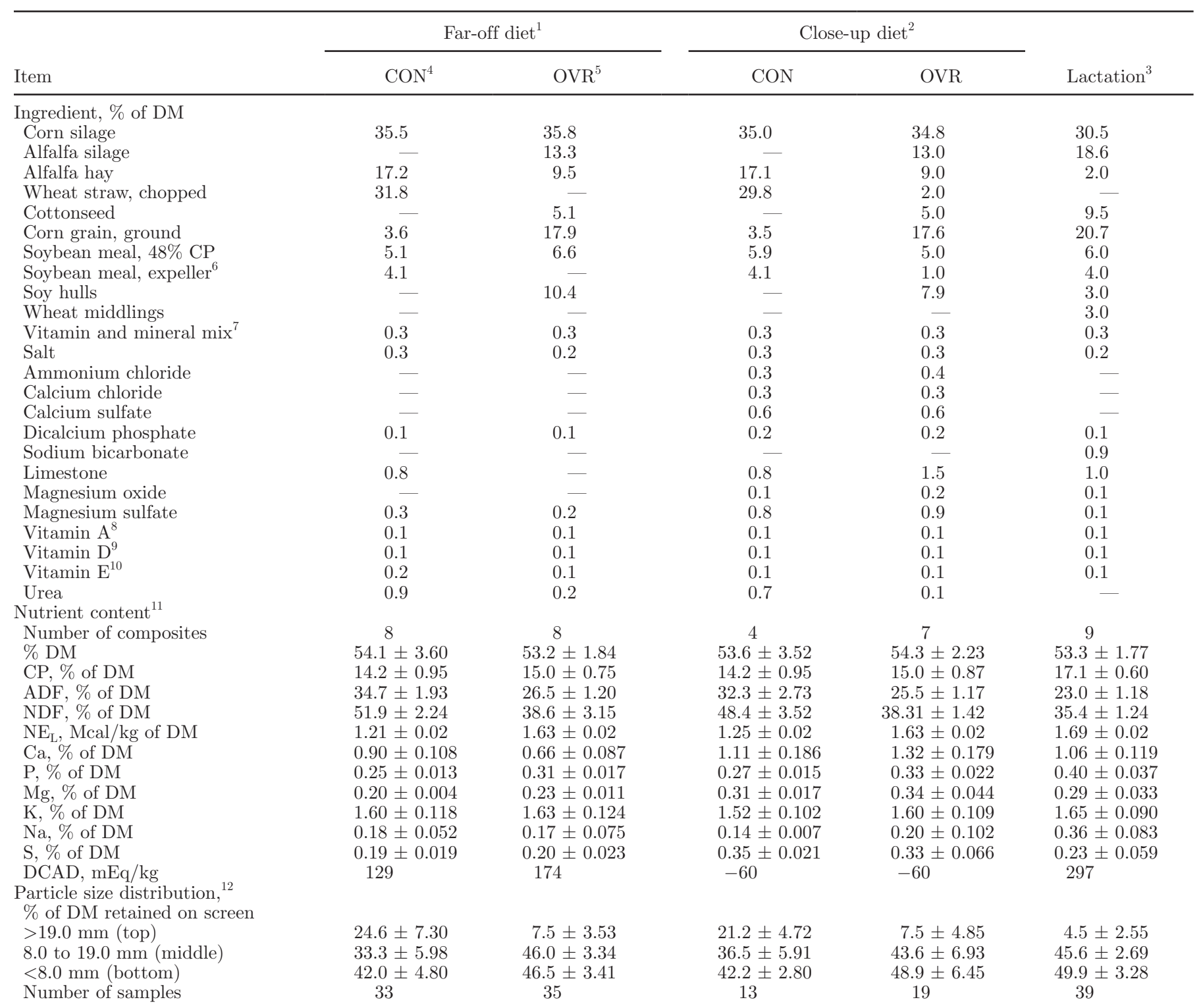

${ }^{1}$ Far-off diets were fed to primiparous cows from -42 d relative to expected parturition to parturition. Far-off diets were fed to multiparous cows from $-65 \mathrm{~d}$ to $-22 \mathrm{~d}$ relative to expected parturition.

${ }^{2}$ Close-up diets were fed from $-21 \mathrm{~d}$ relative to expected parturition to parturition to multiparous cows only.

${ }^{3}$ Long-stemmed alfalfa hay was topdressed $(\sim 2.3 \mathrm{~kg} / \mathrm{d})$ onto the lactation ration from parturition through 10 DIM.

${ }^{4}$ Diet fed for ad libitum intake and formulated to control (CON) $\mathrm{NE}_{\mathrm{L}}$ intake to $100 \%$ of $\mathrm{NRC}$ (2001) recommendation for $\mathrm{NE}_{\mathrm{L}}$ for mature dry cows. Approximately $3.5 \mathrm{~kg} / \mathrm{cow}$ water was added to adjust DM to that of the overfed (OVR) diet.

${ }^{5}$ Diet fed for ad libitum intake to cows in the OVR treatment group to achieve an $\mathrm{NE}_{\mathrm{L}}$ intake in excess $(\sim 150 \%)$ of the NRC $(2001)$ recommendation for $\mathrm{NE}_{\mathrm{L}}$ for mature dry cows. This diet was fed at restricted intake (RES treatment group) to achieve an $\mathrm{NE}_{\mathrm{L}}$ intake of $80 \%$ of the $\mathrm{NRC}$ (2001) recommendation for $\mathrm{NE}_{\mathrm{L}}$ for mature dry cows.

${ }^{6}$ SoyPLUS (West Central Soy, Ralston, IA).

${ }^{7}$ Contained a minimum of $5.0 \% \mathrm{Mg}, 10.0 \% \mathrm{~S}, 7.5 \% \mathrm{~K}, 2.0 \% \mathrm{Fe}, 3.0 \% \mathrm{Zn}, 3.0 \% \mathrm{Mn}, 5,000 \mathrm{mg} / \mathrm{kg} \mathrm{Cu}, 250 \mathrm{mg} / \mathrm{kg} \mathrm{I}, 40 \mathrm{mg} / \mathrm{kg} \mathrm{Co}, 150 \mathrm{mg} / \mathrm{kg} \mathrm{Se}$, $2,200,000 \mathrm{IU} / \mathrm{kg}$ of vitamin $\mathrm{A}, 660,000 \mathrm{IU} / \mathrm{kg}$ of vitamin $\mathrm{D}_{3}$, and $22,000 \mathrm{IU} / \mathrm{kg}$ of vitamin $\mathrm{E}$.

${ }^{8}$ Contained $30,000 \mathrm{kIU} / \mathrm{kg}$.

${ }^{9}$ Contained $5,009 \mathrm{kIU} / \mathrm{kg}$.

${ }^{10}$ Contained 44,000 IU $/ \mathrm{kg}$.

${ }^{11}$ Nutrient composition based on 4-wk feed ingredient composites. Means are presented with standard deviations.

${ }^{12}$ Particle size data are presented as means with standard deviations. A 3-screen Penn State Particle Size Separator (Pennsylvania State University) was used for measurements. Lactation diet samples used to determine particle size did not include the long-stemmed alfalfa hay that was topdressed onto the diet from parturition through 10 DIM. 
Table 2. Macronutrient composition of feed refusals compared with composition of the diet at the time offered to multiparous and primiparous Holstein cows

\begin{tabular}{|c|c|c|c|c|c|}
\hline \multirow[b]{2}{*}{ Nutrient fraction } & \multicolumn{2}{|c|}{ Far-off $^{1}$} & \multicolumn{2}{|c|}{ Close-up ${ }^{2}$} & \multirow{2}{*}{$\frac{\text { Lactation }}{\text { All cows }^{5}}$} \\
\hline & $\mathrm{CON}^{3}$ & $\mathrm{OVR}^{4}$ & $\mathrm{CON}$ & OVR & \\
\hline Refusals $^{6}$ & $59.5 \pm 6.49$ & $42.4 \pm 6.63$ & $59.3 \pm 3.64$ & $39.0 \pm 3.68$ & $39.4 \pm 5.68$ \\
\hline Difference $^{7}$ & 7.6 & 3.8 & 10.9 & 0.7 & 4.1 \\
\hline \multicolumn{6}{|l|}{$\mathrm{ADF}, \%$ of $\mathrm{DM}$} \\
\hline \multicolumn{6}{|l|}{$\mathrm{CP}, \%$ of $\mathrm{DM}$} \\
\hline Refusals & $11.4 \pm 1.67$ & $15.0 \pm 1.22$ & $10.8 \pm 1.77$ & $15.4 \pm 1.44$ & $17.4 \pm 1.97$ \\
\hline Difference & -2.9 & 0.0 & -3.0 & 0.4 & 0.3 \\
\hline \multicolumn{6}{|c|}{ Total digestible nutrients, $\%$ of DM } \\
\hline Refusals & $63.1 \pm 1.90$ & $68.0 \pm 2.02$ & $63.5 \pm 1.05$ & $68.8 \pm 1.19$ & $67.4 \pm 10.60$ \\
\hline Difference & 0.6 & -2.2 & 0.5 & -1.7 & -5.0 \\
\hline \multicolumn{6}{|l|}{$\mathrm{NE}_{\mathrm{L}}, \mathrm{Mcal} / \mathrm{kg}$} \\
\hline
\end{tabular}

${ }^{1}$ Far-off diets were fed to primiparous heifers from -42 d relative to expected parturition to parturition. Far-off diets were fed to multiparous cows from $-65 \mathrm{~d}$ to $-22 \mathrm{~d}$ relative to expected parturition.

${ }^{2}$ Close-up diets were fed from $-21 \mathrm{~d}$ relative to expected parturition to parturition to multiparous cows only.

${ }^{3} \mathrm{CON}=$ controlled energy intake prepartum. This diet was fed for ad libitum intake to control $\mathrm{NE}_{\mathrm{L}}$ intake to $100 \%$ of the NRC (2001) recommendation for $\mathrm{NE}_{\mathrm{L}}$ for mature dry cows.

${ }^{4} \mathrm{OVR}=$ cows overfed energy prepartum. This diet was fed for ad libitum intake to achieve an $\mathrm{NE}_{\mathrm{L}}$ intake in excess $(\sim 150 \%)$ of the NRC $(2001)$ recommendation for $\mathrm{NE}_{\mathrm{L}}$ for mature dry cows. This diet was fed at restricted intake (RES treatment group) to achieve an $\mathrm{NE}_{\mathrm{L}}$ intake of $80 \%$ of the NRC (2001) recommendation for $\mathrm{NE}_{\mathrm{L}}$ for mature dry cows.

${ }^{5}$ One lactation diet was fed to all cows at parturition. Refusal samples containing long-stemmed alfalfa hay that was topdressed $(\sim 2.3 \mathrm{~kg} / \mathrm{d})$ onto the diet from parturition through 10 DIM were not included in composites used for composition analysis.

${ }^{6}$ Means \pm standard deviations.

${ }^{7}$ Differences calculated as composition of feed refusal minus composition of diet offered; therefore, positive numbers represent increases in the nutrient concentration in refused feed.

tie stall. Cows were milked twice daily at 0300 and 1500 $\mathrm{h}$ and milk yields were recorded. Consecutive morning and evening milk samples were taken weekly when cows were $\geq 6$ DIM and each week thereafter through 60 DIM. Milk samples were composited in proportion to milk yield, preserved (800 Broad Spectrum Microtabs II; D\&F Control Systems Inc., San Ramon, CA) and analyzed for contents of fat, protein, lactose, and urea N, as well as SCC (Dairy Lab Services, Dubuque, IA).

Cow BW was recorded once weekly for all cows after the morning milking and before the morning feeding. Additionally, cows were weighed after parturition and calf birth weight was recorded. A BCS (Wildman et al., 1982) was assigned independently by 4 individuals once per week and the median score was used for each cow.

Individual feed ingredients were sampled weekly and DM content (AOAC, 1995) was determined for each component. Rations were adjusted for DM of ingredients on a weekly basis. Because of potential differences in DM content of the prepartum TMR, water (2.5 to $3.5 \mathrm{~kg} / \mathrm{cow}$ ) was added to the CON TMR to adjust its DM content to within 1 to $5 \%$ of DM of the OVR TMR. Weekly feed ingredient samples were frozen at $-20^{\circ} \mathrm{C}$ and then composited monthly for analysis of $\mathrm{DM}, \mathrm{CP}, \mathrm{NDF}, \mathrm{ADF}, \mathrm{Ca}, \mathrm{P}, \mathrm{K}$, and $\mathrm{Mg}$ by wet chemistry techniques at a commercial laboratory (Dairy One, Ithaca, NY). For energy calculations, Dairy One used the Ohio State summative energy equation to predict total digestible nutrients (TDN) at maintenance and the NRC (2001) equations to calculate $\mathrm{NE}_{\mathrm{L}}$ at $3 \times$ maintenance, with the Van Soest variable discount system used for forages. Particle size distribution was determined weekly for each of the TMR samples using a Penn State Particle Separator with 2 screens (Table 1). To help evaluate potential sorting of prepartum diets or the lactation diet, feed refusals were sampled weekly before refusals were removed and weighed in the morning. These samples were frozen at $-20^{\circ} \mathrm{C}$ and composited by cow every 4 wk for analysis of DM, CP, $\mathrm{NDF}, \mathrm{ADF}, \mathrm{Ca}, \mathrm{P}, \mathrm{K}$, and $\mathrm{Mg}$ by wet chemistry techniques as done for individual feed ingredients (Dairy One). The difference between nutrient composition of the TMR as fed compared with the nutrient composition of the refused feed is summarized in Table 2.

Energy balance was calculated both pre- and postpartum for each multiparous cow using equations from NRC 
(2001). Intake of $\mathrm{NE}_{\mathrm{L}}$ was calculated by multiplying the daily $\mathrm{DMI}$ by $\mathrm{NE}_{\mathrm{L}}$ density in the diet determined using the monthly composites of individual feed ingredients as described earlier. Maintenance $\mathrm{NE}_{\mathrm{L}}$ (Mcal) was calculated as $\mathrm{BW}^{0.75} \times 0.080$. Pregnancy requirements for $\mathrm{NE}_{\mathrm{L}}(\mathrm{Mcal})$ were calculated as $[(0.00318 \times$ day of gestation -0.0352$) \times($ calf birth weight/45)]/0.218. Requirements of $\mathrm{NE}_{\mathrm{L}}$ for milk production were calculated as $(0.0929 \times$ fat $\%)+(0.0547 \times$ protein $\%)+(0.0395$ $\times$ lactose $\%)$.

For primiparous cows, maintenance $\mathrm{NE}_{\mathrm{L}}$, pregnancy requirement for $\mathrm{NE}_{\mathrm{L}}$, and $\mathrm{NE}_{\mathrm{L}}$ for milk production were calculated with the same equations used for cows. Additionally, retained energy $(\mathbf{R E})$ or $\mathrm{NE}_{\mathrm{G}}$ required during pregnancy was calculated using equation $11-2$ in NRC (2001). Data from the University of Illinois Dairy Research Unit were used to obtain average age at first calving and an estimate of mature BW of multiparous cows in the herd. These data were used to estimate mature shrunk BW, target weight at first breeding, and target age of first pregnancy for primiparous cows. Age of each primiparous cow and pretrial BW were used to estimate growth rate before the trial. The expanded equation for calculation of RE was as follows:

$$
\begin{gathered}
\mathrm{RE}=0.0635 \times\{0.891 \times[(0.96 \times \text { current } \mathrm{BW}) \\
\times(478 / \text { mature shrunk } \mathrm{BW})]\}^{0.75} \times\{0.956 \times[\text { target } \\
\mathrm{BW} \text { at first breeding }-(0.96 \times \text { current } \mathrm{BW})] / \\
[\text { target age at first pregnancy }- \text { current age }]\}^{1.097} .
\end{gathered}
$$

After substituting in herd estimates, the following equation resulted, with herd estimates in bold:

$$
\begin{gathered}
\mathrm{RE}=0.0635 \times\{0.891 \times[(0.96 \times \text { current } \mathrm{BW}) \\
\times(478 / \mathbf{6 5 4} \mathbf{~ k g})]\}^{0.75} \times\{0.956 \times[\mathbf{3 7 5} \mathbf{~ k g}-(0.96 \\
\times \text { current } \mathrm{BW})] /[\mathbf{5 0 0} \mathbf{d}-\text { current age }]\}^{1.097} .
\end{gathered}
$$

Weekly energy changes in body reserves were calculated using change in BW each week of the trial. To reduce noise in the data for BW loss or gain each week, a 3-point smoothing method was used. Using tables in NRC (2001), energy values for BW change (Mcal/kg) were multiplied by BW gain or loss $(\mathrm{kg})$ to yield weekly energy changes from body reserves. Positive changes indicated animals were storing energy; negative numbers indicated energy supplied from body reserves. To address differences in body reserve composition and energy supplied by each BW loss, BCS of the cow each week was considered and used for calculations of energy reserve changes weekly (NRC, 2001).
Estimates of ME and MP supply and balance were estimated using the NRC (2001) model (Table 3). Default nutrient values were used for grain mix ingredients, whereas monthly composites analyzed by Dairy One were used to adjust default values for alfalfa silage, alfalfa hay, corn silage, cottonseed, and wheat straw. Means for DMI, BW, BCS, milk yield, and milk components were used for inputs into the model.

\section{Statistical Analyses}

Before statistical analysis, daily measurements for DMI and milk yield were condensed to weekly means. To avoid problems with fitting covariance structure, pre- and postpartum data and data from the day of parturition were analyzed separately. Data were analyzed as a randomized design using the MIXED procedure of SAS (SAS Institute Inc., Cary, NC) with the following model:

$$
\begin{gathered}
\mathrm{y}_{\mathrm{ijk} l}=\mu \\
+\mathrm{W}_{\mathrm{i}}+\mathrm{P}_{\mathrm{j}}+\mathrm{WP}_{\mathrm{ij}}+\mathrm{T}_{\mathrm{k}}+\mathrm{WT}_{\mathrm{ik}} \\
+\mathrm{PT}_{\mathrm{jk}}+\mathrm{WPT}_{\mathrm{ijk}}+\mathrm{C}_{(\mathrm{ijk}) \mathrm{l}}
\end{gathered}
$$

where $\mathrm{y}_{\mathrm{ijkl}}=$ an observation from the ith week relative to calving, jth parity, kth treatment, and lth cow; $\mu=$ the grand mean; $\mathrm{W}_{\mathrm{i}}=$ effect of the ith week; $\mathrm{P}_{\mathrm{j}}=$ effect of the jth parity; $\mathrm{WP}_{\mathrm{ij}}=$ effect of the week by parity interaction; $\mathrm{T}_{\mathrm{k}}=$ effect of the kth treatment; $\mathrm{WT}_{\mathrm{ik}}=$ effect of the week by treatment interaction; $\mathrm{PT}_{\mathrm{jk}}=$ effect of the parity by treatment interaction; $\mathrm{WPT}_{\mathrm{ijk}}=$ effect of the week by parity by treatment interaction; and $\mathrm{C}_{(\mathrm{ijk}) 1}=$ random experimental error from the lth cow nested within the ith week, jth parity, and kth treatment.

The REPEATED statement was used for variables measured over time (BW, BCS, DMI, milk yield, and milk components). For data from the day of parturition and variables not measured over time (BW change and BCS change), the MIXED procedure of SAS was used without the REPEATED statement, and week relative to calving and all associated interactions were removed from the model. The random error term used for all mixed models was cow within parity and treatment and the covariance structure yielding the lowest Akaike's information criterion was used (Littell et al., 1998). Using this methodology, an autoregressive covariance structure was the best fit for all data in this experiment. Degrees of freedom were estimated by using the Satterthwaite option in the model statement. When significant interactions with treatment occurred, linear contrast statements were constructed to explore them. Significance was declared when $P<0.05$, and tenden- 
Table 3. National Research Council (2001) model inputs and estimates used to predict $\mathrm{NE}_{\mathrm{L}}$, ME, and MP supply and balance for prepartum diets and lactation diet fed to multiparous and primiparous Holstein cows

\begin{tabular}{|c|c|c|c|c|c|c|c|c|c|c|c|}
\hline \multirow{2}{*}{ Variable } & \multicolumn{6}{|c|}{ Far-off ${ }^{1}$} & \multirow{2}{*}{\multicolumn{3}{|c|}{$\frac{\text { Close-up }{ }^{2}}{\text { Multiparous }}$}} & \multicolumn{2}{|c|}{ Lactation } \\
\hline & \multicolumn{3}{|c|}{ Multiparous } & \multicolumn{3}{|c|}{ Primiparous } & & & & $\frac{\text { Multiparous }}{\text { All cows }}{ }^{6}$ & $\frac{\text { Primiparous }}{\text { All cows }}$ \\
\hline \multicolumn{12}{|l|}{ Inputs } \\
\hline DMI, kg/d & 13.2 & 16.8 & 7.0 & 8.5 & 10.7 & 7.6 & 12.8 & 13.1 & 7.3 & 20.7 & 16.2 \\
\hline BW, kg & 693 & 749 & 672 & 602 & 635 & 633 & 715 & 791 & 698 & 637 & 555 \\
\hline DIM & - & - & - & - & - & - & - & - & - & 30 & 30 \\
\hline Milk, $\mathrm{kg} / \mathrm{d}$ & - & - & - & - & - & - & - & - & - & 34.8 & 26.8 \\
\hline Fat, $\%$ & - & - & - & - & - & - & - & - & - & 3.79 & 4.03 \\
\hline Protein, \% & - & - & - & - & - & - & - & - & - & 2.82 & 2.82 \\
\hline Lactose, $\%$ & - & - & - & - & - & - & - & - & - & 4.70 & 4.92 \\
\hline \multicolumn{12}{|l|}{ Estimates } \\
\hline $\mathrm{NE}_{\mathrm{L}}, \mathrm{Mcal} / \mathrm{kg}$ of $\mathrm{DM}$ & 1.37 & 1.61 & 1.69 & 1.32 & 1.59 & 1.59 & 1.36 & 1.61 & 1.64 & 1.63 & 1.66 \\
\hline MP balance, $\mathrm{g} / \mathrm{d}$ & 412 & 661 & 22 & 89 & 258 & 59 & 318 & 326 & -40 & 14 & 7 \\
\hline
\end{tabular}

${ }^{1}$ Far-off diets were fed to primiparous heifers from -42 d relative to expected parturition to parturition. Far-off diets were fed to multiparous cows from $-65 \mathrm{~d}$ to $-22 \mathrm{~d}$ relative to expected parturition.

${ }^{2}$ Close up diets were fed from $-21 \mathrm{~d}$ relative to expected parturition to parturition to multiparous cows only.

${ }^{3} \mathrm{CON}=$ controlled energy intake prepartum. This diet was fed for ad libitum intake to control $\mathrm{NE}_{\mathrm{L}}$ intake to $100 \%$ of the NRC (2001) recommendation for $\mathrm{NE}_{\mathrm{L}}$ for mature dry cows.

${ }^{4} \mathrm{OVR}=$ cows overfed energy prepartum. This diet was fed for ad libitum intake to achieve an $\mathrm{NE}_{\mathrm{L}}$ intake in excess $(\sim 150 \%)$ of the NRC $(2001)$ recommendation for $\mathrm{NE}_{\mathrm{L}}$ for mature dry cows.

${ }^{5} \mathrm{RES}=$ restricted energy intake prepartum. The OVR diet was fed at restricted intake to achieve an $\mathrm{NE}_{\mathrm{L}}$ intake of $80 \%$ of the $\mathrm{NRC}(2001)$ recommendation for $\mathrm{NE}_{\mathrm{L}}$ for mature dry cows.

${ }^{6}$ One lactation diet was fed to all cows at parturition. These inputs and estimates do not consider the long-stemmed alfalfa hay that was topdressed $(\sim 2.3 \mathrm{~kg} / \mathrm{d})$ onto the diet from parturition through 10 DIM.

cies or trends in all data were declared at $0.05<P \leq$ 0.10 .

\section{RESULTS AND DISCUSSION}

At dry-off, there were no differences $(P>0.13)$ among dietary treatment groups for parity $(1.7 \pm 0.9)$, previous lactation 305-d mature-equivalent milk yield $(11,752 \pm 1,297 \mathrm{~kg})$, fat yield $(475 \pm 60 \mathrm{~kg})$, or BCS $(3.01 \pm 0.08)$ for multiparous cows. In the multiparous cow group, 305-d mature-equivalent protein yield (358 $\pm 41 \mathrm{~kg}$ ) was numerically lower for CON and RES cows than for OVR cows $(P=0.11)$. For primiparous cows, no pretreatment differences were observed $(P>0.43)$ among dietary treatment groups for predicted age at first calving $(25.9 \pm 2.2 \mathrm{mo})$, PTA for milk yield (92 \pm $248 \mathrm{~kg})$, fat yield $(3 \pm 6 \mathrm{~kg})$, and protein yield $(2 \pm 6$ $\mathrm{kg}$ ), or BCS (3.57 \pm 0.08$)$. Multiparous cows consumed far-off diets for $42 \pm 0.5 \mathrm{~d}$ and close-up diets for $24 \pm$ $4.9 \mathrm{~d}$ before parturition. Primiparous cows consumed prepartum diets for $40 \pm 4.8 \mathrm{~d}$. One multiparous cow in the OVR group developed toxic mastitis in wk 4 of lactation and was killed; therefore, this group had $n=7$ for wh 5 to 8 of lactation. For all other levels of dietary treatment group by parity, $\mathrm{n}=8$ during lactation.

In the discussion of results, we recognize that multiparous cows were fed diets for a longer period prepartum compared with primiparous cows. Therefore, we acknowledge that our discussion of parity differences includes the possibility that some observed differences may have resulted at least in part from the duration that experimental diets were fed. This fact cannot be entirely separated from the expected biological differences between primiparous and multiparous cows with regard to DMI, BW, and milk production. Despite this point, it is invaluable to gain insight on how prepartum dietary management of mixed groups of primiparous and multiparous cows might be affected in a practical production setting. Therefore, for prepartum data, dryoff data points for multiparous cows are provided as a point of reference and statistical comparisons between parities were made for matching periods only. 


\section{Dietary Characteristics}

Addition of water to the far-off or close-up CON diets was effective in equalizing DM content among diets, adjusting the DM percentage to $<1.0 \%$ difference $(P>$ $0.27)$ compared with the OVR diets (Table 1). Inclusion of chopped wheat straw in the CON diets resulted in profiles of particle size distribution that differed from the OVR diet (Table 1). The lactation diet is also presented in Table 1 for comparison. Retention of particles on the top screen of the Penn State box was greater $(P<0.001)$ for the CON diet than for the OVR diet, whereas more $(P<0.001)$ of the particles were retained on the middle and bottom screens for the OVR diet compared with CON. When considering effective fiber as the sum of percentages of particles retained on the top 2 screens, not surprisingly that of the CON diet was greater $(P<0.001)$ than that of the OVR diet.

Because of the expected differences in particle size, we determined if there was evidence for sorting by the cows between the prepartum diets (Table 2). High moisture content of some of the refusal samples (from spilled drinking water) did not allow accurate measurement of particle size distribution with the Penn State box; therefore, chemical composition of the refusals was used. As illustrated by the increase in NDF and ADF content in feed refusals compared with feed offered (Table 2), some sorting occurred on all diets, but perhaps to a greater degree for the CON diets compared with others. Because of the small number of refusal samples obtained for some diets and the inability to coordinate enough refusal samples with monthly feed sample composites to be meaningful, statistical comparisons were not made among diets. Standard errors associated with measures of nutrient composition of the refusals indicated variability associated with individual cow preference to sort the TMR as noted by others (Leonardi et al., 2005; Leonardi and Armentano, 2007). For the CON diet, CP tended to decrease in feed refusals compared with the feed offered, whereas calculated TDN and $\mathrm{NE}_{\mathrm{L}}$ contents tended to increase compared with either the OVR or the lactation diets. It is not clear how cows could have sorted protein components from energy components more easily on the CON diet than on the OVR or lactation diets. Perhaps a greater inclusion of corn silage and the addition of more urea to the CON diets compared with the other diets may have contributed to this result.

Supplies of ME and MP predicted by the NRC (2001) model are summarized in Table 3. As designed, the ME supply for multiparous cows met requirements for CON, exceeded requirements for OVR cows, and was deficient for RES cows. Intake of the CON diet by primiparous cows before the experiment began was predicted by the
NRC (2001) model to be $1.5 \mathrm{~kg}$ greater than actually observed. Therefore, as a result of calculations in the model for energy for growth and lower DMI during the experiment, ME supply was deficient for primiparous cows fed CON in addition to RES cows. With the exception of multiparous cows fed the close-up RES diet, MP supply and balance were adequate and positive for the feeding periods. Supply of vitamins and minerals was also generally adequate among the diets fed, as predicted by NRC model. Because MP was predicted to be adequate for all diets yet supplied at different levels among diets, it is not plausible to make inferences about effects of prepartum protein supply on response variables in this trial. Therefore, with regard to nutrient supply, differences in response variables among prepartum diets can be assumed to be attributable primarily to prepartum energy supply.

\section{DMI}

As designed, cows assigned to RES diets prepartum had lower DMI as a percentage of BW than either OVR or CON cows (Figure 1; $P<0.0001$ ). The DMI for both primiparous and multiparous cows in the OVR group declined in the $3 \mathrm{wk}$ preceding parturition. In comparison, cows in the CON and RES groups maintained prepartum intake at 1.6 and $1.1 \%$ of BW, respectively. Modeling prepartum DMI data to predict changes before and after parturition has revealed that multiparous cows are expected to decrease DMI to a greater degree than primiparous cows (Grummer et al., 2004), as was the case in the present study. Formulating diets with wheat straw to increase concentration of NDF has been used successfully to combat large decreases in DMI prepartum in other studies (Minor et al., 1998; Beever, 2006; Dann et al., 2006), a strategy that also worked for CON cows in our study.

Type of NDF may influence the success of limiting DMI. VandeHaar et al. (1999) used cottonseed hulls to increase NDF in the diet, which did not prevent multiparous cows from over consuming energy and experiencing large changes before parturition; however, primiparous cows had a smaller change in DMI immediately prepartum. Holcomb et al. (2001) were able to prevent large changes in DMI prepartum by restricting the amount of DM fed using diets containing bermudagrass hay and formulated to contain $44 \%$ or $39 \%$ NDF. Unfortunately, energy concentration in those diets was not reported, and thus, it is difficult to determine how these changes may have interacted with plane of energy intake prepartum. More research is needed with regard to determining the optimal fiber type that can be used as a TMR component to control intake due to the behavior of the fiber in the rumen. 


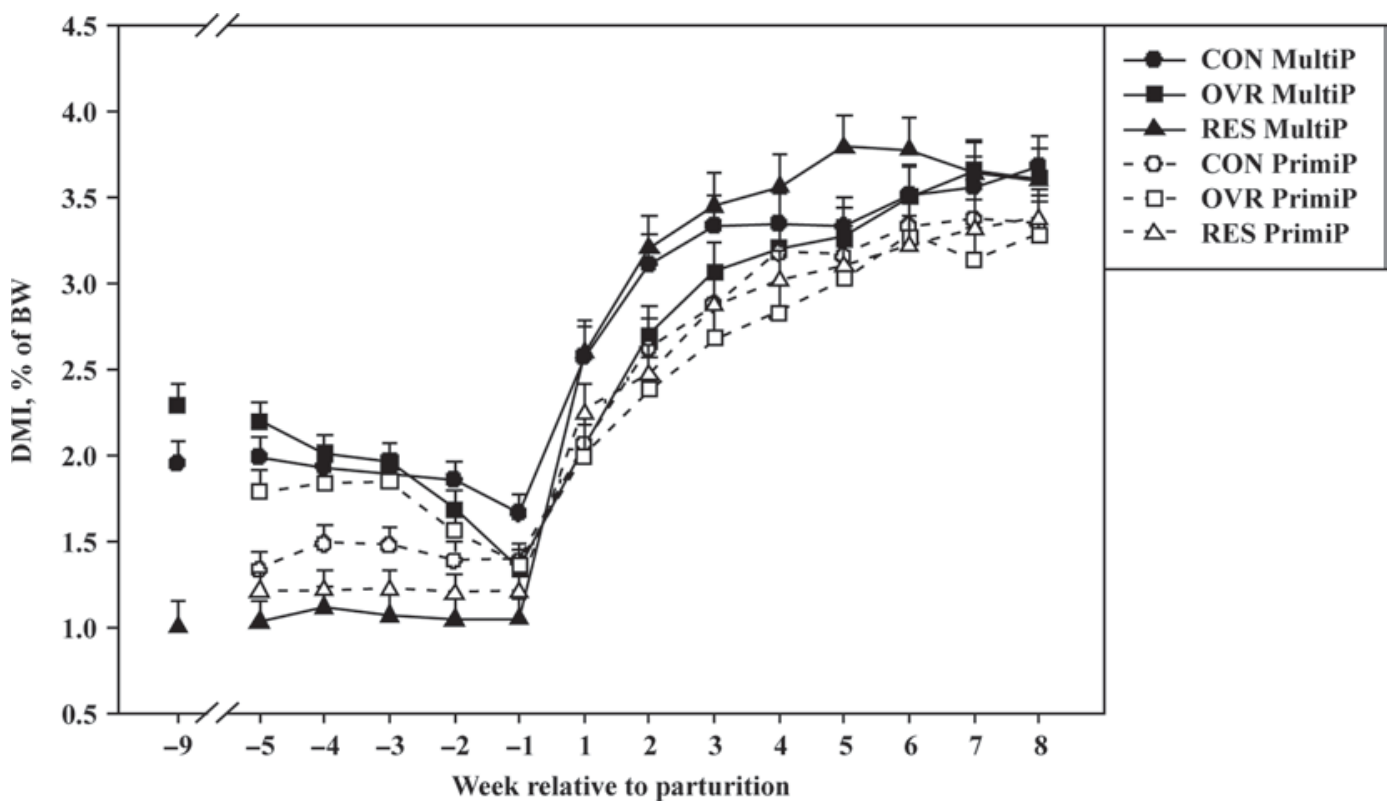

Figure 1. Least squares means for DMI as a percentage of BW for multiparous (MultiP) and primiparous (PrimiP) Holsteins fed different diets prepartum. Pooled standard error bars are shown. Prepartum diet abbreviations: CON = controlled energy intake prepartum, fed for ad libitum intake to control $\mathrm{NE}_{\mathrm{L}}$ intake to $100 \%$ of the $\mathrm{NRC}(2001)$ recommendation for $\mathrm{NE}_{\mathrm{L}}$ for mature dry cows; OVR = cows overfed energy prepartum, diet fed for ad libitum intake to achieve an $\mathrm{NE}_{\mathrm{L}}$ intake in excess $(\sim 150 \%)$ of the $\mathrm{NRC}(2001)$ recommendation for $\mathrm{NE}_{\mathrm{L}}$ for mature dry cows; RES = restricted energy intake prepartum, OVR diet fed at restricted intake to $80 \%$ of the NRC (2001) recommendation for $\mathrm{NE}_{\mathrm{L}}$ for mature dry cows. Multiparous cows were fed prepartum diets from dry off through parturition ( $\sim 65 \mathrm{~d})$, and primiparous cows were fed prepartum diets from $35 \mathrm{~d}$ before expected parturition through parturition. Week -9 for multiparous cows corresponds to means for the first week dietary treatments were fed to multiparous cows. At parturition, all cows were fed the same lactation diet. Prepartum: parity, $P<0.06$; diet, $P<0.0001$; week, $P<0.0001$; parity $\times$ diet, $P=0.01$; parity $\times$ week, $P=0.08$; diet $\times$ week, $P<0.0001$; parity $\times$ diet $\times$ week, $P>0.60$. Postpartum: parity, $P<0.002$; diet, $P=0.28$; week, $P<0.0001 ; 2$ - and 3 -way interactions of main effects, $P>0.50$.

During the first 3 wk postpartum, OVR cows tended $(P=0.08)$ to consume less DM as a percentage of BW than RES cows, which was largely a result of differences in the multiparous group $(P=0.07)$. Interestingly, within the OVR group, DMI as a percentage of BW during the first $3 \mathrm{wk}$ postpartum did not differ between parity groups $(P=0.33)$. Because of this, DMI $(\mathrm{kg} / \mathrm{d})$ for multiparous cows in the OVR group was similar to that of primiparous cows (Table 4). Therefore, expected parity differences did not exist for this period as they did for CON and RES, when multiparous cows had greater intake than primiparous cows. Prepartum diet did not have a significant effect on DMI as a percentage of BW over the 8 wk of lactation. No dietary effects on DMI $(\mathrm{kg} / \mathrm{d})$ postpartum were observed during either period (Table $4 ; P \geq 0.42$ ). Large changes in DMI prepartum have been related to lower DMI postpartum (Grummer et al., 2004; Drackley et al., 2005); however, preventing a decrease in DMI prepartum by force-feeding refusals through a rumen cannula failed to confer a DMI advantage over control cows postpartum (Bertics et al., 1992).

In an earlier study, DMI as a percentage of BW tended to be lower during the first 10 DIM for cows overfed energy in the far-off dry period compared with cows limited to approximately $100 \%$ of their requirement or restricted to $80 \%$ of requirement prepartum (Dann et al., 2006). A similar effect was observed on DMI $(\mathrm{kg} / \mathrm{d})$ by Douglas et al. (2006). Guo et al. (2007) reported no postpartum differences in DMI for cows fed a transition diet $(1.71 \mathrm{Mcal} / \mathrm{kg})$ around parturition compared with control cows fed a moderate energy $(1.54 \mathrm{Mcal} / \mathrm{kg})$ diet for 4 wk prepartum. Similarly, prepartum plane of energy intake did not affect postpartum DMI for primiparous and multiparous cows (Rabelo et al., 2003). Keeping cows at a constant plane of intake prepartum, but restricting DM fed prepartum to change energy intake also failed to affect DMI postpartum, although cows fed below their energy requirement prepartum had a faster increase in DMI postpartum (Agenäs et al., 2003). Together, these results still leave unanswered questions about how prepartum diet formulation interacts with energy intake prepartum and ultimately affects postpartum DMI; however, most data indicate that avoiding large decreases in DMI prepartum is desirable.

\section{$B C S$ and $B W$}

Pretrial BCS was not different among dietary treatment groups (Table 4; $P=0.41$ ), but was greater for 
Table 4. Least squares means for DMI postpartum, median BCS, and BW changes for multiparous and primiparous Holstein cows fed different diets prepartum

\begin{tabular}{|c|c|c|c|c|c|c|c|c|c|c|}
\hline Variable & \multicolumn{3}{|c|}{ Multiparous } & \multicolumn{3}{|c|}{ Primiparous } & SEM & \multicolumn{3}{|c|}{$P$-value } \\
\hline Wk 1 to 3 & 17.4 & 16.7 & 18.0 & 12.5 & 11.9 & 13.4 & 1.25 & $<0.001$ & 0.49 & 0.99 \\
\hline Wk 1 to 8 & 19.6 & 20.2 & 20.9 & 15.7 & 14.9 & 16.4 & 0.96 & $<0.001$ & 0.42 & 0.94 \\
\hline \multicolumn{11}{|l|}{ BCS, 5-point scale } \\
\hline Initial BCS & 3.21 & 3.02 & 2.81 & 3.58 & 3.50 & 3.62 & 0.143 & $<0.001$ & 0.41 & 0.25 \\
\hline \multicolumn{11}{|l|}{$\mathrm{BW}, \mathrm{kg}$} \\
\hline Initial BW & 682 & 711 & 688 & 569 & 592 & 613 & 23.7 & $<0.001$ & 0.42 & 0.59 \\
\hline Dry period change & $35^{\mathrm{a}}$ & $81^{\mathrm{b}}$ & $18^{\mathrm{a}}$ & $49^{\mathrm{a}}$ & $60^{\mathrm{b}}$ & $39^{\mathrm{a}}$ & 10.3 & 0.57 & $<0.01$ & 0.09 \\
\hline Lactation change & $-43^{\mathrm{a}}$ & $-88^{b}$ & $-20^{\mathrm{a}}$ & $-3^{\mathrm{a}}$ & $-25^{\mathrm{b}}$ & $-23^{\mathrm{a}}$ & 13.9 & $<0.01$ & 0.02 & 0.04 \\
\hline
\end{tabular}

${ }^{\mathrm{a}, \mathrm{b}}$ Main effects of diet in the same row with different superscripts differ $(P \leq 0.05)$.

${ }^{1} \mathrm{CON}=$ controlled energy intake prepartum. This diet was fed for ad libitum intake to control $\mathrm{NE}_{\mathrm{L}}$ intake to $100 \%$ of the NRC (2001) recommendation for $\mathrm{NE}_{\mathrm{L}}$ for mature dry cows.

${ }^{2} \mathrm{OVR}=$ cows overfed energy prepartum. This diet was fed for ad libitum intake to achieve an $\mathrm{NE}_{\mathrm{L}}$ intake in excess $(\sim 150 \%)$ of the NRC $(2001)$ recommendation for $\mathrm{NE}_{\mathrm{L}}$ for mature dry cows.

${ }^{3} \mathrm{RES}=$ restricted energy intake prepartum. The OVR diet was fed at restricted intake to achieve an $\mathrm{NE}_{\mathrm{L}}$ intake of $80 \%$ of the $\mathrm{NRC}(2001)$ recommendation for $\mathrm{NE}_{\mathrm{L}}$ for mature dry cows.

${ }^{4}$ For both BCS and BW, changes were calculated from dry-off through wk -1 relative to parturition for multiparous cows and from wk -5 to wk -1 relative to parturition for primiparous cows.

${ }^{5}$ For both BCS and BW, changes were calculated from wk 1 of lactation through wk 8 of lactation for all cows regardless of parity.

primiparous cows than for multiparous cows $(P<$ 0.001). Likewise, BW was not different among groups before dietary treatments began (Table $4 ; P=0.42$ ) but multiparous cows had a greater $(P<0.001)$ initial BW than did primiparous cows, as expected. These pretrial differences observed between parity groups but not among treatment groups resulted in a covariate that was significant in the statistical model. Graphical presentation of data using covariate adjustment, however, masked important biological differences between the 2 parities that are important for interpretation. Therefore, the data are presented in Table 4 and Figure 2 as least squares means unadjusted for pretrial values.

The BCS of multiparous cow groups was affected $(P$ $=0.01$ ) by dietary treatment from dry-off through wk -6 relative to parturition (Figure 2A). This effect was driven by differences between OVR and RES cows (3.30 and 2.70; $P=0.03$ ). No differences among treatment groups were observed in BW from dry-off through wk -6 in multiparous cows (Figure 2B; $P>0.25$ ).

An interaction between parity and diet affected BCS in the 5 wk preceding parturition (Figure 2A; $P=$ 0.003). This interaction resulted from the difference in response to the RES diet between parities (parity $\times$ diet, $P=0.0002$ ), where primiparous RES cows appeared to gain BCS during the first 2 wk of dietary treatment, but multiparous RES cows tended to maintain BCS. Both primiparous and multiparous cows gained BW as parturition approached (Figure 2B; week, $P<0.0001$ ) as would be expected with increased fetal growth during late pregnancy.

Prepartum diet affected change in BCS before parturition (Table $4 ; P=0.02$ ). Overall change in BCS prepartum was greatest for multiparous cows in the OVR group, which gained almost one-third of a BCS unit, whereas CON and RES cows had a small loss in BCS prepartum. Likely because of the shorter feeding period, smaller changes were observed in BCS for primiparous cows prepartum. It can be difficult to change BCS prepartum as there is a strong relationship between BCS at dry-off and BCS at parturition (Friggens et al., 2004). In some studies, however, overfeeding energy to cows prepartum has resulted in increased BCS during the dry period compared with either controlling energy intake or restricting energy intake (Boisclair et al., 1986; Agenäs et al., 2003; Dann et al., 2006; Douglas et al., 2006). VandeHaar et al. (1999) observed that primiparous and multiparous cows fed prepartum diets formulated to meet requirements for energy (1.30 $\mathrm{Mcal} / \mathrm{kg}$ of DM) gained less BCS than cows fed diets formulated to contain $1.61 \mathrm{Mcal} / \mathrm{kg}$ of $\mathrm{NE}_{\mathrm{L}}$ when diets were fed for $25 \mathrm{~d}$ before expected parturition. Other studies reported no significant change in BCS as a result of overfeeding energy prepartum (Grum et al., 1996; Mashek and Beede, 2001; Dann et al., 2005; Guo et al., 2007). Length of feeding period varied in these studies from 4 to $10 \mathrm{wk}$ prepartum, and different strategies were employed to control energy intake, including 


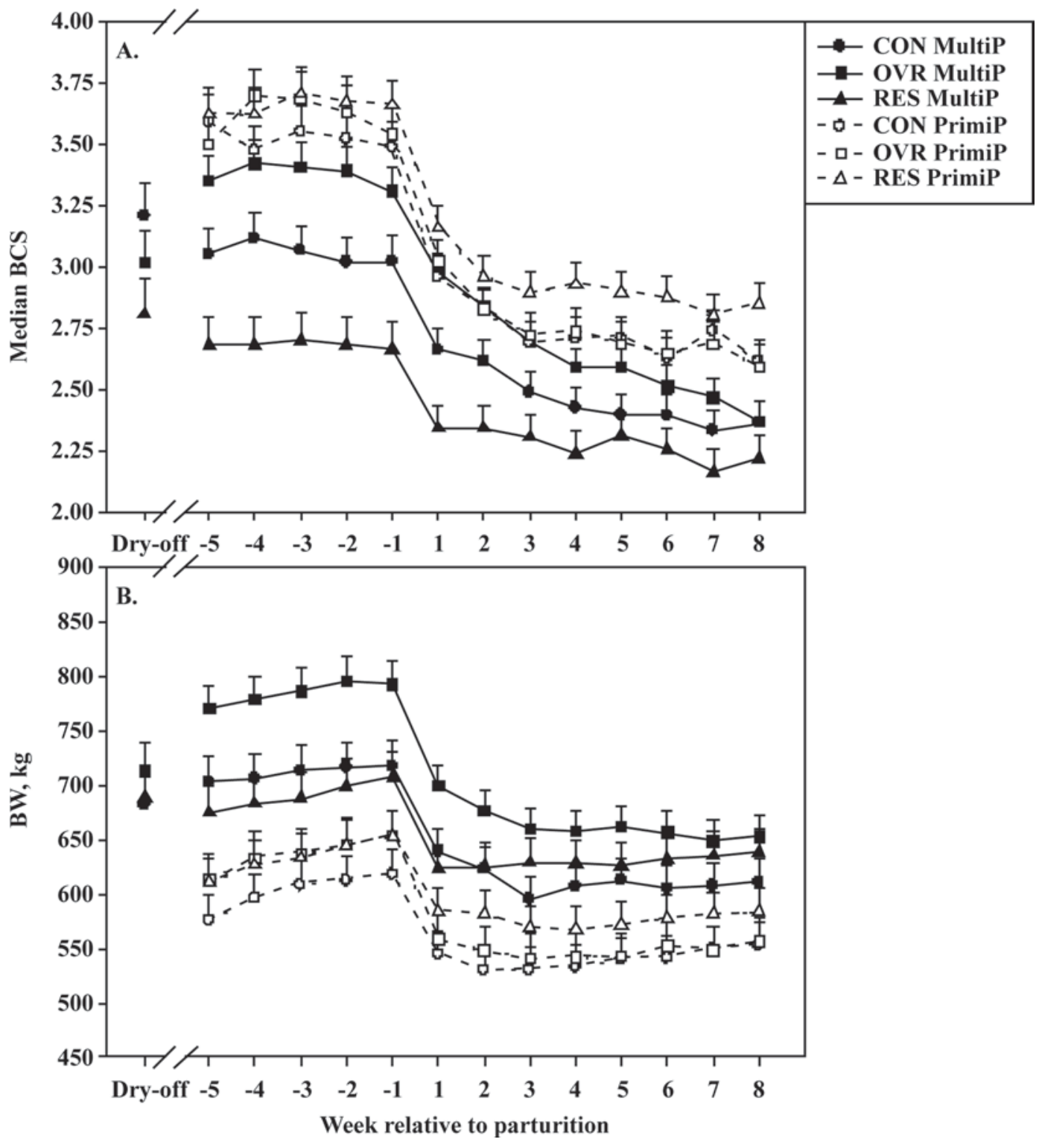

Figure 2. Least squares means of weekly median BCS (5-point scale) and weekly BW for multiparous (MultiP) and primiparous (PrimiP) Holsteins fed different diets prepartum. Pooled standard error bars are shown. Prepartum diet abbreviations: CON $=$ controlled energy intake prepartum, fed for ad libitum intake to control $\mathrm{NE}_{\mathrm{L}}$ intake to $100 \%$ of the $\mathrm{NRC}(2001)$ recommendation for $\mathrm{NE}_{\mathrm{L}}$ for mature dry cows; OVR $=$ cows overfed energy prepartum, diet fed for ad libitum intake to achieve an $\mathrm{NE}_{\mathrm{L}}$ intake in excess $(\sim 150 \%)$ of the NRC (2001) recommendation for $\mathrm{NE}_{\mathrm{L}}$ for mature dry cows; RES = restricted energy intake prepartum, OVR diet fed at restricted intake to $80 \%$ of the NRC (2001) recommendation for $\mathrm{NE}_{\mathrm{L}}$ for mature dry cows. Multiparous cows were fed prepartum diets from dry off through parturition ( $\left.\sim 65 \mathrm{~d}\right)$, and primiparous cows were fed prepartum diets from $35 \mathrm{~d}$ before expected parturition through parturition. The "dry-off" point indicated on the graph represents means for the week before cows consuming their respective prepartum diets. At parturition, all cows were fed the same lactation diet. Panel A: Prepartum: parity, $P<0.0001$; diet, $P=0.01$; week, $P=0.04$; parity $\times$ diet, $P=0.003$; other interactions of main effects, $P>0.29$. Postpartum: parity, $P<0.0001$; diet, $P=0.42$; week, $P=0.04$; parity $\times$ diet, $P=0.004$; parity $\times$ week, $P=0.03$; diet $\times$ week, $P=0.01$; parity $\times$ diet $\times$ week, $P=0.39$. Panel B: Prepartum: parity, $P<0.0001$; diet, $P=0.04$; week, $P<0.0001$; parity $\times$ week, $P=0.03$; other interactions of main effects, $P>0.15$. Postpartum: parity, $P<0.0001$; diet, $P=0.26$; week, $P<0.0001$; diet $\times$ week, $P=0.08$; parity $\times$ diet $\times$ week, $P=0.08$; other interactions of main effects, $P \geq 0.11$.

feeding fat, formulating diets to contain more NDF, and physical restriction of intake, which may help explain differences among studies.

The magnitude of change in BW among dietary treatment groups prepartum tended to be different in primiparous and multiparous cows (diet $\times$ parity, $P=$ 0.09). Multiparous cows in the OVR group gained the most BW prepartum compared with multiparous RES or CON cows $(P<0.01)$, whereas within primiparous cows, BW gain was not different among treatments 
$(P \geq 0.15)$. Overall trends in BW gain prepartum were typical of cows approaching parturition. Similar to BCS, change in BW was greatest for cows overfed energy prepartum in some studies (Vande Haar et al., 1999; Dann et al., 2006; Douglas et al., 2006), but no dietary effects were observed in others (Grum et al., 1996; Douglas et al., 2004).

Dietary treatments did not affect calf BW $(P=0.90)$, similar to results of others (Rabelo et al., 2003; Dann et al., 2005, 2006; Douglas et al., 2006; Guo et al., 2007). As expected, calves born to primiparous cows had lower BW $(P=0.02)$ than calves born to multiparous cows. Calving difficulty scores did not vary among dietary groups $(P=0.21)$.

All cows lost BCS and BW postpartum (Figure 2). An interaction between diet and parity affected BCS postpartum $(P=0.004)$, which resulted from differences in BCS changes between parities within the OVR and RES groups (diet $\times$ parity, $P=0.001$ ). This interaction can be explained by the fact that multiparous OVR cows continued to decrease in BCS through the 8 wk of lactation studied, whereas BCS for primiparous OVR cows leveled off after wk 4 in lactation $(P$ $=0.02$ ). Primiparous RES cows lost more BCS immediately postpartum than did multiparous RES cows $(P<0.001)$. Regardless of dietary treatment group, primiparous cows lost approximately two-thirds of a BCS unit postpartum (Table 4). Multiparous OVR cows lost more BCS than did multiparous CON or RES cows, which likely influenced the interaction of parity and diet observed postpartum. The slope of BW loss postpartum was not affected by prepartum diet (Figure 2B). Overall BW loss was greatest for multiparous OVR cows compared with other diet by parity groups (Table 4 ; diet $\times$ parity, $P=0.04$ ). Overall BW change for primiparous CON cows was very small compared with OVR and RES groups, even though BCS loss was similar across these treatment groups.

None of the cow groups was over- or underconditioned at parturition according to current recommendations (Overton and Waldron, 2004). Primiparous cows carried more BCS at parturition; however, at an average BCS of 3.35, this was not considered excessive. Magnitude of BCS loss postpartum can be associated with several factors. Cows that have greater BCS at parturition tend to lose more BCS postpartum than those in moderate to thinner condition (Broster and Broster, 1998). Change in BCS is also related to milk and milk fat yield (Broster and Broster, 1998; Friggens et al., 2004; Berry et al., 2007 ), and cows with higher merit for milk production are expected to have larger changes in BCS postpartum (Waltner et al., 1993). Multiparous OVR cows in this study perhaps had potential for greater milk yield as indicated by mean previous mature-equivalent milk yield data that approached significance. This tendency could partially explain why these cows had larger changes in BCS postpartum.

In other studies where cows were overfed energy prepartum, greater BCS loss postpartum was also observed compared with cows with controlled or restricted intake (Boisclair et al., 1986; Dann et al., 2006) or cows that were fed less nutrient-dense diets prepartum (Mashek and Beede, 2001). On the other hand, postpartum BW change was not affected by prepartum diet in those studies. Agenäs et al. (2003), Douglas et al. (2004, 2006), and Guo et al. (2007) did not observe prepartal dietary treatment effects on BCS or BW change postpartum; however, numerically larger differences in BCS were observed for cows that were overfed compared with those fed near or below their requirement for energy.

Fewer data are available to make parity conclusions. In Mashek and Beede (2001), BW were not reported and parity effects for BCS were not discussed. Rabelo et al. (2003) reported that postpartum BCS and BW changes were not affected by parity or interaction with prepartum dietary treatment when either a moderate or high energy diet was fed for 4 wk before parturition. Because diets of different energy concentration (1.57 or $1.67 \mathrm{Mcal} / \mathrm{kg}$ ) were fed postpartum by Rabelo et al. (2003), it is more difficult to separate prepartum and postpartum effects. Primiparous cows in that study fed a moderate energy diet prepartum tended to have lower BW at $70 \mathrm{~d}$ postpartum than those fed a higher energy diet prepartum. Multiparous cows lost more BW and BCS than primiparous cows in the study by VandeHaar et al. (1999); however, energy intake prepartum did not affect those changes.

\section{Milk Yield and Composition}

Prepartum diet did not affect milk yield for the first 3 wk postpartum, regardless of parity (Table 5; $P=$ 0.29 ); however, over the 8 -wk lactation period, cows in the OVR group tended $(P=0.10)$ to produce more milk than those in CON and RES groups. This difference was observed only in the multiparous group (Figure 3). Interestingly, although pretrial differences in previous mature-equivalent milk yield or components were not significant $(P \geq 0.13)$ for multiparous cows, the tendency for differences in milk yield among dietary groups was negated $(P=0.27)$ when milk yields were adjusted for previous mature-equivalent yield. In another study, restricting energy to $80 \%$ of requirement prepartum compared with allowing cows to consume energy ad libitum prepartum did not significantly affect milk yield over 105 DIM (Douglas et al., 2006). Milk yield during the first 10 DIM for cows allowed to consume $100 \%$ of energy requirements was numeri- 
Table 5. Least squares means for milk yield, dairy efficiency, and milk composition for multiparous and primiparous Holstein cows fed different diets prepartum

\begin{tabular}{|c|c|c|c|c|c|c|c|c|c|}
\hline Variable & \multicolumn{3}{|c|}{ Multiparous } & \multicolumn{3}{|c|}{ Primiparous } & SEM & \multicolumn{2}{|c|}{$P$-value } \\
\hline Wk 1 to 3 & 26.9 & 35.7 & 28.1 & 22.5 & 23.3 & 24.0 & 2.36 & $<0.001$ & 0.29 \\
\hline Wk 1 to 8 & $33.3^{\mathrm{a}}$ & $38.9^{\mathrm{a}}$ & $31.1^{\mathrm{b}}$ & $26.4^{\mathrm{a}}$ & $27.7^{\mathrm{a}}$ & $27.4^{\mathrm{b}}$ & 2.11 & $<0.001$ & 0.10 \\
\hline \multicolumn{10}{|c|}{$3.5 \%$ FCM yield ${ }^{4} \mathrm{~kg} / \mathrm{d}$} \\
\hline Wk 2 to 3 & $42.7^{\mathrm{a}}$ & $54.8^{\mathrm{b}}$ & $39.4^{\mathrm{a}}$ & $33.6^{\mathrm{a}}$ & $37.4^{\mathrm{b}}$ & $36.5^{\mathrm{a}}$ & 3.84 & 0.002 & 0.05 \\
\hline Wk 2 to 3 & $2.2^{\mathrm{a}}$ & $2.9^{\mathrm{b}}$ & $1.9^{\mathrm{a}}$ & $2.3^{\mathrm{a}}$ & $2.8^{\mathrm{b}}$ & $2.5^{\mathrm{a}}$ & 0.23 & 0.33 & 0.01 \\
\hline Wk 2 to 8 & $2.2^{\mathrm{a}}$ & $2.6^{\mathrm{b}}$ & $1.9^{\mathrm{a}}$ & $2.2^{\mathrm{a}}$ & $2.5^{\mathrm{b}}$ & $2.2^{\mathrm{a}}$ & 0.13 & 0.32 & 0.001 \\
\hline \multicolumn{10}{|c|}{ Milk components, wk 2 and 3} \\
\hline \multicolumn{10}{|c|}{ Fat } \\
\hline$\%$ & $3.50^{\mathrm{a}}$ & $4.66^{\mathrm{b}}$ & $3.90^{\mathrm{ab}}$ & $4.52^{\mathrm{a}}$ & $5.27^{\mathrm{b}}$ & $4.49^{\mathrm{ab}}$ & 0.500 & 0.04 & 0.06 \\
\hline $\mathrm{kg} / \mathrm{d}$ & $1.16^{\mathrm{a}}$ & $1.72^{\mathrm{b}}$ & $1.13^{\mathrm{a}}$ & $1.05^{\mathrm{a}}$ & $1.26^{\mathrm{b}}$ & $1.13^{\mathrm{a}}$ & 0.156 & 0.12 & 0.02 \\
\hline \multicolumn{10}{|l|}{ Protein } \\
\hline $\mathrm{SCC}, \times 1,000$ & 535 & 1,218 & 247 & 219 & 250 & 383 & 245.6 & 0.05 & 0.16 \\
\hline Urea $\mathrm{N}, \mathrm{mg} / \mathrm{dL}$ & 15.8 & 16.7 & 15.2 & 15.9 & 16.9 & 18.0 & 1.77 & 0.44 & 0.83 \\
\hline \multicolumn{10}{|c|}{ Milk components, first $8 \mathrm{wk}$} \\
\hline \multicolumn{10}{|c|}{ Fat } \\
\hline$\%$ & 3.53 & 3.82 & 4.02 & 4.08 & 4.17 & 3.87 & 0.207 & 0.13 & 0.59 \\
\hline $\mathrm{kg} / \mathrm{d}$ & $1.19^{\mathrm{a}}$ & $1.50^{\mathrm{b}}$ & $1.26^{\mathrm{ab}}$ & $1.10^{\mathrm{a}}$ & $1.17^{\mathrm{b}}$ & $1.10^{\mathrm{ab}}$ & 0.094 & 0.02 & 0.11 \\
\hline \multicolumn{10}{|l|}{ Protein } \\
\hline$\%$ & 2.77 & 2.75 & 2.93 & 2.86 & 2.80 & 2.82 & 0.085 & 0.91 & 0.48 \\
\hline $\mathrm{kg} / \mathrm{d}$ & 0.95 & 1.10 & 0.91 & 0.80 & 0.79 & 0.80 & 0.069 & 0.001 & 0.29 \\
\hline \multicolumn{10}{|l|}{ Lactose } \\
\hline$\%$ & $4.78^{\mathrm{a}}$ & $4.57^{\mathrm{b}}$ & $4.74^{\mathrm{ab}}$ & $4.96^{\mathrm{a}}$ & $4.90^{\mathrm{b}}$ & $4.90^{\mathrm{ab}}$ & 0.065 & $<0.001$ & 0.11 \\
\hline $\mathrm{kg} / \mathrm{d}$ & 1.63 & 1.84 & 1.52 & 1.35 & 1.40 & 1.39 & 0.110 & 0.002 & 0.27 \\
\hline $\mathrm{SCC}, \times 1,000$ & 598 & 1,132 & 502 & 299 & 135 & 227 & 205.8 & 0.002 & 0.38 \\
\hline Urea $\mathrm{N}, \mathrm{mg} / \mathrm{dL}$ & 16.0 & 16.0 & 14.9 & 16.1 & 15.3 & 16.4 & 0.98 & 0.71 & 0.91 \\
\hline
\end{tabular}

${ }^{\mathrm{a}, \mathrm{b}}$ Main effects of diet in the same row with different superscripts differ $(P \leq 0.05)$.

${ }^{1} \mathrm{CON}=$ controlled energy intake prepartum. This diet was fed for ad libitum intake to control NE $\mathrm{L}_{\mathrm{L}}$ intake to $100 \%$ of the NRC (2001) recommendation for $\mathrm{NE}_{\mathrm{L}}$ for mature dry cows.

${ }^{2} \mathrm{OVR}=$ cows overfed energy prepartum. This diet was fed for ad libitum intake to achieve an $\mathrm{NE}_{\mathrm{L}}$ intake in excess $(\sim 150 \%)$ of the NRC $(2001)$ recommendation for $\mathrm{NE}_{\mathrm{L}}$ for mature dry cows.

${ }^{3} \mathrm{RES}=$ restricted energy intake prepartum. The OVR diet was fed at restricted intake to achieve an $\mathrm{NE}_{\mathrm{L}}$ intake of $80 \%$ of the $\mathrm{NRC}(2001)$ recommendation for $\mathrm{NE}_{\mathrm{L}}$ for mature dry cows.

${ }^{4}$ Fat-corrected milk $=0.4324 \times($ milk yield $)+16.2162 \times($ fat yield $)$. Milk components were not sampled until cows were $\geq 10$ DIM; therefore, FCM was not calculated for the first week.

${ }^{5}$ Defined as $3.5 \%$ FCM $(\mathrm{kg})$ divided by DMI $(\mathrm{kg})$.

cally higher compared with restricted feeding or ad libitum intake of energy during the far-off dry period, regardless of close-up period diet (Dann et al., 2006). This numerical tendency $(2.5 \mathrm{~kg} / \mathrm{d}$ more milk per cow $)$ persisted over the 8 wk of lactation studied.

Diet affected milk composition during the first $3 \mathrm{wk}$ of lactation (Table 5). Cows in the OVR group had higher milk fat percentage and yield $(\mathrm{kg} / \mathrm{d})$ than did CON cows $(P \leq 0.03)$. The RES cows had lower fat yield $(P=0.01)$ than OVR cows and tended to have lower $(P=0.07)$ percentage milk fat. Lactose as a percentage of milk yield was lower for OVR than for CON $(P=0.001)$. These dietary effects did not persist over the 8-wk lactation period (Table 5), but composition differences contributed to greater 3.5\% FCM yield during the first $3 \mathrm{wk}$ of lactation for OVR cows than for CON or RES cows (Table 5; $P=0.05$ ). Somatic cell count and MUN were unaffected by prepartum diet $(P$ $\geq 0.16)$.

In other studies, restricted feeding prepartum did not significantly affect milk yield in multiparous cows, but resulted in lower milk fat percentage compared with ad libitum feeding (Holcomb et al., 2001; Dann et al., 2006). Prepartum diets with greater NFC content resulted in greater milk yield, greater milk fat and protein percentages, and greater protein yield compared with cows fed 


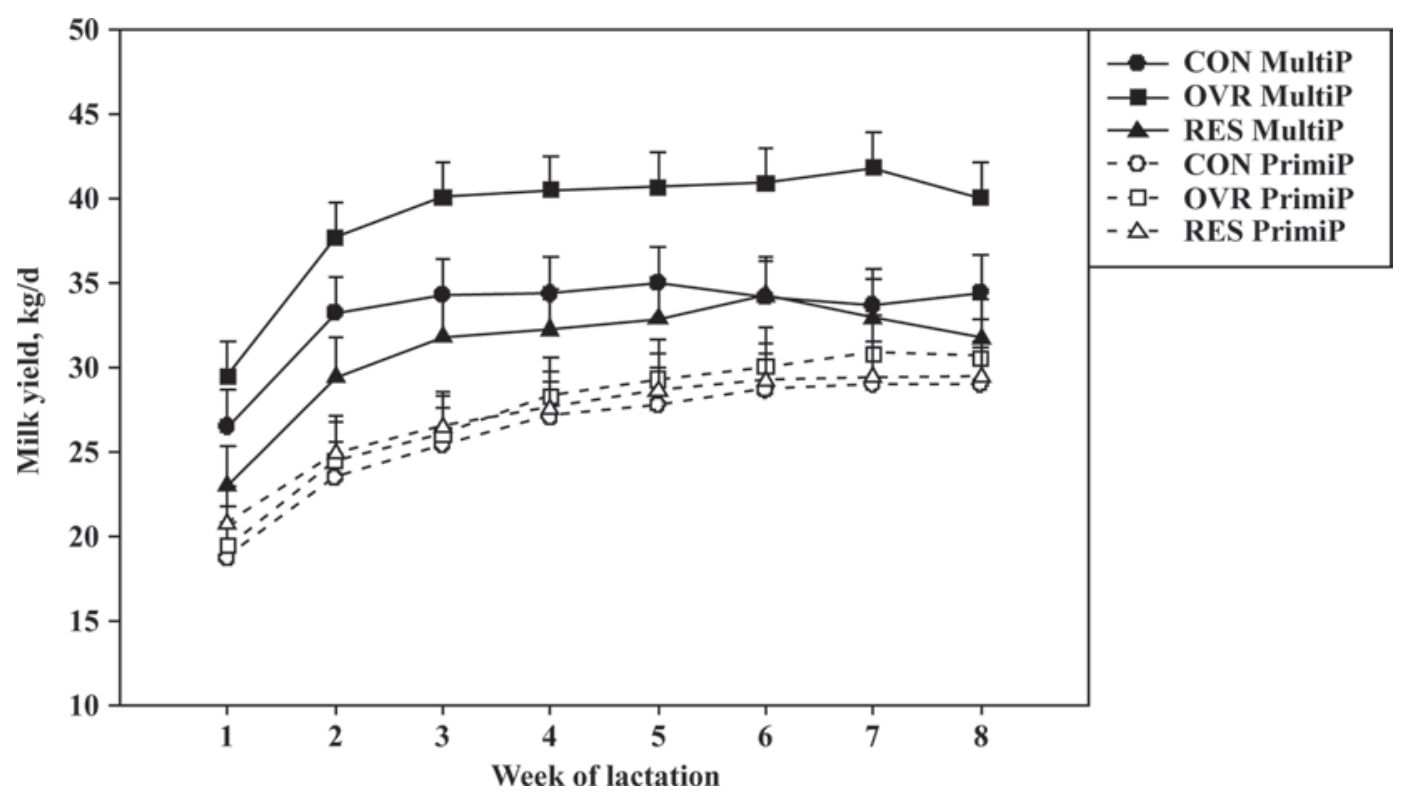

Figure 3. Least squares means of weekly milk yield for multiparous (MultiP) and primiparous (PrimiP) Holsteins fed different diets prepartum. Pooled standard error bars are shown. Prepartum diet abbreviations: CON = controlled energy intake prepartum, fed for ad libitum intake to control $\mathrm{NE}_{\mathrm{L}}$ intake to $100 \%$ of the $\mathrm{NRC}$ (2001) recommendation for $\mathrm{NE}_{\mathrm{L}}$ for mature dry cows; OVR = cows overfed energy prepartum, diet fed for ad libitum intake to achieve an $\mathrm{NE}_{\mathrm{L}}$ intake in excess $(\sim 150 \%)$ of the $\mathrm{NRC}(2001)$ recommendation for $\mathrm{NE}_{\mathrm{L}}$ for mature dry cows; $\mathrm{RES}=$ restricted energy intake prepartum, OVR diet fed at restricted intake to $80 \%$ of the NRC (2001) recommendation for NE $E_{\mathrm{L}}$ for mature dry cows. Wk 1 to 3: parity, $P<0.0001$; diet, $P=0.29$; week, $P<0.0001$; parity $\times$ week, $P=0.004$; other interactions of main effects, $P>0.19$. Wk 1 to 8: parity $P<0.0001$; diet, $P=0.10$; week, $P<0.0001$, parity $\times$ week, $P=0.02$; other interactions of main effects, $P>0.18$.

a standard dietary NFC level (Minor et al., 1998). On the other hand, energy-corrected milk yield from cows that were restricted to $75 \%$ of energy requirements prepartum was numerically higher than for those fed at or above (127\%) requirement prepartum, although the authors reported no significant diet or time by diet effects (Agenäs et al., 2003). Others found no effect of prepartum energy intake on milk yield or components (Boisclair et al., 1986; Rabelo et al., 2003; Guo et al., 2007). In a study that used both primiparous and multiparous cows, Rabelo et al. (2003) found that feeding moderate energy diets to primiparous cows prepartum resulted in greater milk fat percentage and yield as well as greater yield of $3.5 \%$ FCM compared with those fed higher energy prepartum. Body condition score at parturition for cows in the present study and in Rabelo et al. (2003) were similar (approximately 3.50), and cows mobilized similar amounts of BCS postpartum. In contrast to our results, therefore, energy density of postpartum diets may have contributed to differences observed in milk yield or components in Rabelo et al. (2003).

Efficiency calculations have been used as a measure of how economically DM is converted to energy-corrected milk (Hutjens, 2005). These calculations can also be used to evaluate how much mobilization from body reserves occurs in support of lactation. As summarized in Table 5, cows in all groups in this study had milk efficiency calculations of $>1.9$. This value, combined with high milk fat values (Table 5), is highly indicative of extensive mobilization of adipose lipid reserves, a phenomenon linked to unfavorable health and metabolic status postpartum (Gearhart et al., 1990; Bobe et al., 2004). Although these efficiency data may not be entirely atypical for cows in early lactation, it is remarkable that the apparent efficiency for the OVR group was double that for the RES group within multiparous cows. Primiparous cows had greater BCS at the beginning of the study and had similar DMI and FCM yield among treatments as discussed. This may explain why dairy efficiency calculations were more consistent among treatments in primiparous groups.

\section{Energy Balance}

As designed, cows in the OVR groups were in more positive $\mathrm{NE}_{\mathrm{L}}$ balance as a percentage of requirements prepartum compared with the CON or RES groups (Figure 4A; $P<0.01$ ). Because RE requirements for growth were included for the primiparous cow calculations, calculated balance was much lower than for multiparous cows within both the OVR and CON groups. This fact, combined with DMI for primiparous cows that were lower than predicted before the experiment 
resulted in the primiparous CON group consuming only $65 \%$ of their calculated energy requirement and OVR cows consuming $107 \%$ of the energy requirement. Removal of RE requirements from calculations showed that primiparous cows achieved $82 \%$ and $123 \%$ of the energy requirement for late gestation in CON and OVR groups, respectively, which was still lower than targeted. Multiparous CON cows consumed $112 \%$ of their energy requirement in the $5 \mathrm{wk}$ preceding parturition and OVR cows consumed 167\% of their requirement prepartum. In both parity groups, targeted values for energy consumption as a percentage of requirements were achieved in the RES group and were $80 \%$ for multiparous cows and $76 \%$ for primiparous cows.

Regardless of parity, cows in the OVR group had a marked change in energy balance during the 3 wk preceding parturition. This change was especially notable for the multiparous group, falling from $160 \%$ of requirements in wk -3 relative to parturition to less than $72 \%$ during the first week of lactation. Even though the magnitude of change was not as large for primiparous cows in the OVR group (117 to $70 \%$ ), the change was drastic compared with either parity in the CON or RES groups, which had very little change in energy balance prepartum. Dietary effects persisted postpartum (diet, $P=0.002$ ), with cows in the OVR group tending to take longer to approach positive energy balance than either CON or RES cows (diet $\times$ week, $P=0.07$ ). Perhaps mostly as a result of lower DMI, primiparous cows were in more negative energy balance postpartum than were multiparous cows $(P=0.008)$. A combination of greater DMI postpartum and lower FCM yield most likely contributed to more positive energy balance for multiparous cows in the RES group compared with other groups (diet $\times$ week, $P<0.03$ ).

Overfeeding energy to cows in the dry period has yielded similar results in other studies. Cows overfed in the far-off dry period were in more negative energy balance during the first 10 DIM, although over the 8-wk lactation period these effects had disappeared (Dann et al., 2006). On the other hand, overfeeding cows during the far-off period followed by restricting intake to $80 \%$ of energy requirements in the close-up period resulted in a trend for this group to be in more negative energy balance over the 8 wk of lactation compared with other treatment combinations. Similarly, cows overfed energy prepartum took much longer to reach positive energy balance postpartum and had a larger energy balance deficit during the first $4 \mathrm{wk}$ or $8 \mathrm{wk}$ of lactation (Agenäs et al., 2003). Cows fed a higher energy transition diet prepartum were in greater negative energy balance for the first $14 \mathrm{~d}$ postpartum compared with control cows (Guo et al., 2007). In contrast, VandeHaar et al. (1999) and Rabelo et al. (2003) did not observe an effect of prepartum energy intake on postpartum energy balance over the first 70 DIM.

Calculated energy change from body reserves was used to further estimate energy status (Figure 4B), with negative numbers indicating mobilization of body tissue reserves. As might be expected by dietary treatment assignments, multiparous cows in the RES and CON groups had less retention of body energy prepartum compared with their OVR counterparts (diet $x$ week, $P=0.003)$. Not surprisingly, the largest change in body reserve energy was observed between the week before and week after parturition, regardless of parity. During the first $3 \mathrm{wk}$ of lactation, the nadir for change in energy from body reserves was observed in wk 1 after parturition (week, $P<0.0001$ ). Multiparous cows in the OVR group had greater contribution of energy from body reserves postpartum than did primiparous cows in the OVR group $(P=0.02)$. Primiparous cows in the CON group had much less mobilization of body energy stores compared with multiparous cows in the same group $(P=0.04)$. Within the RES group, multiparous and primiparous cows had similar contribution of energy from body reserves postpartum $(P=0.45)$.

Previous research has indicated that most of the body energy changes in early lactation are associated with adipose tissue mobilization (Andrew et al., 1994). Furthermore, the change in body energy (Mcal/ $\mathrm{kg}$ of $\mathrm{BW}$ ) is smallest during the dry period and largest during early lactation. In these experiments, as empty body energy increased, the amount of energy from protein remained stable, whereas the contribution from fat increased linearly with body energy. Based on these known results, it is reasonable to assume that the largest source of body energy mobilization came from adipose stores in the present study. Gut fill is a confounding factor when calculating energy balance or change in energy reserves in early lactation. During the first $60 \mathrm{~d}$ of lactation, gut fill has been reported to be greatest in early lactation compared with the dry period or late lactation (Andrew et al., 1995). This may help to explain why both net energy balance and energy changes from body reserves approached positive values as early as 4 wk postpartum in our study.

\section{General Discussion}

The optimal prepartum dietary management strategy with regard to control of DM and energy intakes has remained controversial. Studies from our laboratory (Grum et al., 1996; Dann et al., 2006; Douglas et al., 2006) and others (Rukkwamsuk et al., 1998, 1999) have indicated that overconsumption of energy prepartum is detrimental to cow health and liver function postpartum, whereas other studies have provided evidence that 

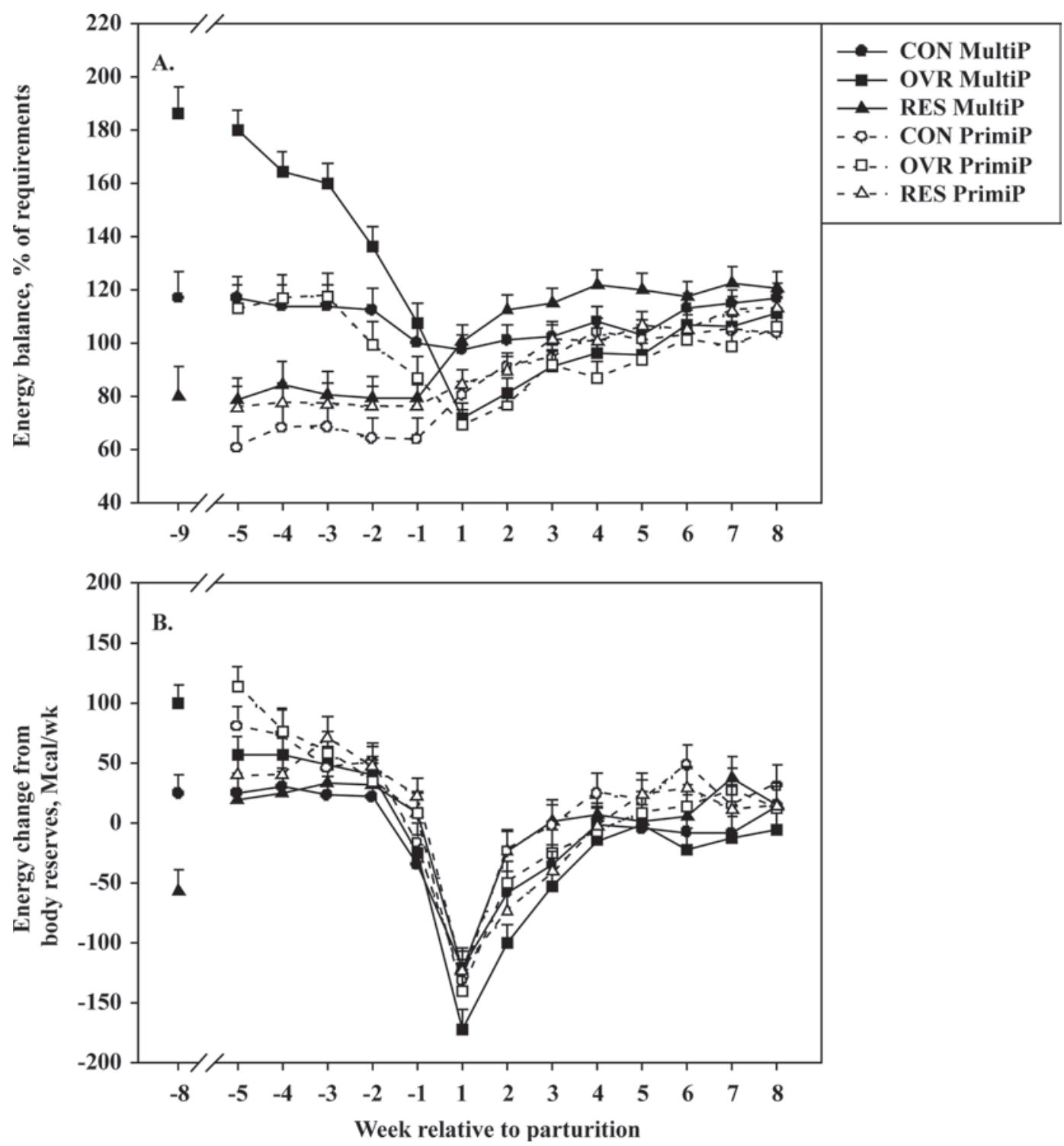

Figure 4. Least squares means of energy balance as a percentage of calculated requirements and weekly energy changes from body reserves in multiparous (MultiP) and primiparous (PrimiP) Holsteins fed different diets prepartum. Pooled standard error bars are shown. Prepartum diet abbreviations: $\mathrm{CON}=$ controlled energy intake prepartum, fed for ad libitum intake to control $\mathrm{NE}_{\mathrm{L}}$ intake to $100 \%$ of the $\mathrm{NRC}$ (2001) recommendation for $\mathrm{NE}_{\mathrm{L}}$ for mature dry cows; OVR = cows overfed energy prepartum, diet fed for ad libitum intake to achieve an $\mathrm{NE}_{\mathrm{L}}$ intake in excess $(\sim 150 \%)$ of the NRC (2001) recommendation for $\mathrm{NE}_{\mathrm{L}}$ for mature dry cows; RES = restricted energy intake prepartum, OVR diet fed at restricted intake to $80 \%$ of the NRC (2001) recommendation for $\mathrm{NE}_{\mathrm{L}}$ for mature dry cows. Multiparous cows were fed prepartum diets from dry off through parturition $(\sim 65 \mathrm{~d})$, and primiparous cows were fed prepartum diets from $35 \mathrm{~d}$ before expected parturition through parturition. Panel A: Week -9 for multiparous cows corresponds to means for the first week dietary treatments were fed to multiparous cows. Based on age and BW prepartum, 2.69 Mcal of $\mathrm{NE}_{\mathrm{L}} / \mathrm{d}$ for growth was considered in prepartum energy balance calculations for primiparous cows. At parturition, all cows were fed the same lactation diet. Prepartum: parity, diet, and week, $P<0.0001$; parity $\times$ diet, $P=0.007$; parity $\times$ week, $P=$ 0.01 ; diet $\times$ week, $P<0.0001$; parity $\times$ diet $\times$ week, $P=0.22$. Postpartum: parity, $P=0.008$; diet, $P=0.002$; week, $P<0.0001$; diet $\times$ week, $P=0.09$; other 2 - and 3 -way interactions of main effects, $P \geq 0.49$. Panel B: Prepartum: parity, $P=0.003$; diet, $P=0.20$; week, $P<0.0001$; diet $\times$ week, $P=0.03$; other 2 - and 3-way interactions, $P=0.55$. Postpartum, wk 1 to 3: week, $P<0.0001$; other main effects and 2- and 3-way interactions of main effects, $P>0.12$. Postpartum, wk 1 to 8: parity, $P=0.05$; diet, $P=0.05$; week, $P<0.0001 ;$ parity $\times$ diet, $P=0.05$; other 2- and 3-way interactions of main effects, $P \geq 0.62$.

supplementing extra energy to cows during the close-up period is beneficial for transition success (Dann et al., 1999; VandeHaar et al., 1999; Rabelo et al., 2005). Large changes in energy balance or DMI around parturition have been linked to lower DMI and milk yield postpartum (Grummer et al., 2004; Drackley et al., 2005). The more stable DMI throughout the dry period in cows fed the CON diet may be an advantage in that regard. 
Previous research in our group indicated that regardless of close-up period energy intake, controlling or restricting energy intake during the far-off dry period had positive effects on transition period performance and health compared with cows allowed to overconsume energy by up to $150 \%$ of recommendations (Dann et al., 2006). Because of limitations on the total number of cows that could be used in that study, it was not possible to include a group of cows that were limited to approximately $100 \%$ of energy requirements over the entire dry period. The present study provides evidence that such a diet prevents large changes in energy balance and mobilization of body reserves during the periparturient period. It will be important now to compare the effects of a diet similar to CON fed throughout the dry period with the conventional far-off and close-up strategy such as that used by Dann et al. (2006).

The addition of chopped wheat straw to prepartum diets was an effective way to control energy intake prepartum and to minimize changes in DMI during the last several days before parturition in multiparous cows. Primiparous cows did not achieve predicted DMI prepartum, and therefore did not consume targeted energy intakes. Even so, changes in DMI and change in energy balance were important in influencing postpartum DMI. Furthermore, our evidence indicates that change in energy balance during the periparturient period might influence how much and how rapidly body stores are lost postpartum, especially for multiparous cows. Postpartum responses to controlling energy intake prepartum by using a bulky diet were much like those seen when physically restricting the amount of feed fed, regardless of parity. It will now be useful to elucidate the effects of prepartum energy intake versus type of prepartum diet fed to determine which has stronger effects, if any, on postpartum variables between parity groups.

Restricting energy intake for 5 wk prepartum was not detrimental to lactation in primiparous cows that were in good body condition at calving, as these cows performed as well as primiparous cows allowed to consume energy ad libitum. More research with primiparous cows with lower BCS would be needed to determine if this conclusion is generally applicable. If the goal is to minimize change in DMI prepartum and BW and BCS change postpartum, however, controlling energy intake prepartum was successful.

Cows did not become obese from overfeeding energy prepartum. Even so, metabolite and health data for these cows (Janovick, 2008) further support the conclusion that maintaining BCS prepartum and minimizing changes in DMI and energy balance in the periparturient period is a more favorable strategy than adding BCS during the dry period. As a result of larger changes in BCS postpartum, cows overfed energy prepartum had greater NEFA and BHBA in plasma postpartum, greater total lipid and triacylglycerol accumulation in liver, and greater incidence of ketosis (Janovick, 2008).

\section{CONCLUSIONS}

Overfeeding energy prepartum resulted in large changes in periparturient energy balance. Even in the absence of overconditioning, the large change in DMI and energy balance prepartum resulted in lower postpartum DMI and greater BCS loss, especially for multiparous cows. Addition of chopped wheat straw was effective at controlling energy intake prepartum, although primiparous cows did not achieve predicted DMI. The CON diets prevented a large decrease in DMI prepartum in both primiparous and multiparous cows. As a result of greater mobilization of body stores, OVR cows had greater milk fat percentage and greater $3.5 \%$ FCM during the first 3 wk postpartum. Controlling or restricting energy intake in primiparous cows was not detrimental to lactational performance over the first 8 wk of lactation. Although prepartum diet effects did not carry over through the entire 8-wk lactation period, controlling energy intake prepartum may help ease the transition to lactation.

\section{ACKNOWLEDGMENTS}

The authors greatly appreciate the assistance given by the staff at the University of Illinois Dairy Research Unit in animal care and data collection. The authors also extend thanks to D. Carlson, R. Ebert, E. French, K. Morgan, K. Moyes, N. Litherland, D. Rincker, and J. Stamey (all of Department of Animal Sciences, University of Illinois) for assistance with sample collection and laboratory procedures. The authors acknowledge the kind gifts of SoyPLUS from West Central Soy (Ralston, IA) and soy hulls from ADM (Decatur, IL).

\section{REFERENCES}

Agenäs, S., E. Burstedt, and K. Holtenius. 2003. Effects of feeding intensity during the dry period. 1. Feed intake, body weight, and milk production. J. Dairy Sci. 86:870-882.

Andrew, S. M., R. A. Erdman, and D. R. Waldo. 1995. Prediction of body composition of dairy cows at three physiological stages from deuterium oxide and urea dilution. J. Dairy Sci. 78:1083-1095.

Andrew, S. M., D. R. Waldo, and R. A. Erdman. 1994. Direct analysis of body composition of dairy cows at three physiological stages. J. Dairy Sci. 77:3022-3033.

AOAC. 1995. Official Methods of Analysis. 16th ed. AOAC International, Arlington, VA.

Beever, D. E. 2006. The impact of controlled nutrition during the dry period on dairy cow health, fertility and performance. Anim. Reprod. Sci. 96:212-226.

Berry, D. P., F. Buckley, and P. Dillon. 2007. Body condition score and live-weight effects on milk production in Irish Holstein-Friesian dairy cows. Animal 1:1351-1359. 
Bertics, S. J., R. R. Grummer, C. Cadorniga-Valino, and E. E. Stoddard. 1992. Effect of prepartum dry matter intake on liver triglyceride concentration and early lactation. J. Dairy Sci. 75:1914-1922.

Bobe, G., J. W. Young, and D. C. Beitz. 2004. Invited review: Pathology, etiology, prevention, and treatment of fatty liver in dairy cows. J. Dairy Sci. 87:3105-3124.

Boisclair, Y., D. G. Grieve, J. B. Stone, O. B. Allen, and G. K. Macleod. 1986. Effect of prepartum energy intake, body condition and sodium bicarbonate on production of cows in early lactation. J. Dairy Sci. 69:2636-2647.

Broster, W. H., and V. J. Broster. 1998. Body score of dairy cows. J. Dairy Res. 65:155-173.

Broster, W. H., and V. J. Tuck. 1967. Experiments on the nutrition of the dairy heifer. J. Agric. Sci. 69:465-477.

Dann, H. M., N. B. Litherland, J. P. Underwood, M. Bionaz, A. D'Angelo, J. W. McFadden, and J. K. Drackley. 2006. Diets during far-off and close-up dry periods affect periparturient metabolism and lactation in multiparous cows. J. Dairy Sci. 89:3563-3577.

Dann, H. M., D. E. Morin, G. A. Bollero, M. R. Murphy, and J. K. Drackley. 2005. Prepartum intake, postpartum induction of ketosis, and periparturient disorders affect the metabolic status of dairy cows. J. Dairy Sci. 88:3249-3264.

Dann, H. M., G. A. Varga, and D. E. Putnam. 1999. Improving energy supply to late gestation and early postpartum dairy cows. J. Dairy Sci. 82:1765-1778.

Douglas, G. N., T. R. Overton, H. G. Bateman II, H. M. Dann, and J. K. Drackley. 2006. Prepartal plane of nutrition, regardless of dietary energy source, affects periparturient metabolism and dry matter intake in Holstein cows. J. Dairy Sci. 89:2141-2157.

Douglas, G. N., T. R. Overton, H. G. Bateman II, and J. K. Drackley, 2004. Peripartal metabolism and production of Holstein cows fed diets supplemented with fat during the dry period. J. Dairy Sci. 87:4210-4220.

Drackley, J. K., and H. M. Dann. 2005. New concepts in nutritional management of dry cows. Adv. Dairy Technol. 17:11-23.

Drackley, J. K., H. M. Dann, G. N. Douglas, N. A. J. Guretzky, N. B. Litherland, J. P. Underwood, and J. J. Loor. 2005. Physiological and pathological adaptations in dairy cows that may increase susceptibility to periparturient diseases and disorders. Ital. J. Anim. Sci. 4:323-344.

Friggens, N. C., J. B. Andersen, T. Larsen, O. Aaes, and R. J. Dewhurst. 2004. Priming the dairy cow for lactation: A review of dry cow feeding strategies. Anim. Res. 53:453-473.

Gardner, R. W., L. W. Smith, and R. L. Park. 1988. Feeding management of dairy heifers for optimal lifetime productivity. J. Dairy Sci. 71:996-999.

Gearhart, M. A., C. R. Curtis, H. N. Erb, R. D. Smith, C. J. Sniffen, L. E. Chase, and M. D. Cooper. 1990. Relationship of changes in condition score to cow health in Holsteins. J. Dairy Sci. 73:31323140.

Grant, R. J., and J. L. Albright. 1995. Feeding behavior and management factors during the transition period in dairy cattle. J. Anim. Sci. 73:2791-2803.

Grum, D. E., J. K. Drackley, R. S. Younker, D. W. LaCount, and J. J. Veenhuizen. 1996. Nutrition during the dry period and hepatic lipid metabolism of periparturient dairy cows. J. Dairy Sci. 79:1850-1864.

Grummer, R. R., D. G. Mashek, and A. Hayirli. 2004. Dry matter intake and energy balance in the transition period. Vet. Clin. Food Anim. 20:447-470.

Guo, J., R. R. Peters, and R. A. Kohn. 2007. Effect of a transition diet on production performance and metabolism in periparturient dairy cows. J. Dairy Sci. 90:5247-5258.

Holcomb, C. S., H. H. Van Horn, H. H. Head, M. B. Hall, and C. J. Wilcox. 2001. Effects of prepartum dry matter intake and forage percentage on postpartum performance of lactating dairy cows. J. Dairy Sci. 84:2051-2058.
Hutjens, M. F. 2005. Feed efficiency and its economic impact on large herds. Pages 186-191 in Proc. Southwest Nutr. Management Conf., Tucson, AZ.

Janovick, N. A. 2008. Prepartum energy intake and its relationship to periparturient inflammation and metabolic dysfunction. PhD Diss. Univ. Illinois, Urbana.

Lacasse, P., E. Block, L. A. Guilbault, and D. Petitclerc. 1993. Effect of plane of nutrition of dairy heifers before and during gestation on milk production, reproduction, and health. J. Dairy Sci. 76:34203427.

Leonardi, C., and L. E. Armentano. 2007. Short communication: Feed selection by dairy cows fed individually in a tie-stall or as a group in a free-stall barn. J. Dairy Sci. 90:2386-2389.

Leonardi, C., F. Giannico, and L. E. Armentano. 2005. Effect of water addition on selective consumption (sorting) of dry diets by dairy cattle. J. Dairy Sci. 88:1043-1049.

Littell, R. C., P. R. Henry, and C. B. Ammerman. 1998. Statistical analysis of repeated measures data using SAS procedures. J. Anim. Sci. 76:1216-1231.

Mashek, D. G., and D. K. Beede. 2001. Peripartum responses of dairy cows fed energy-dense diets for 3 or 6 weeks prepartum. J. Dairy Sci. $84: 115-125$.

Minor, D. J., S. L. Trower, B. D. Strang, R. D. Shaver, and R. R. Grummer. 1998. Effects of nonfiber carbohydrate and niacin on periparturient metabolic status and lactation of dairy cows. J. Dairy Sci. 81:189-200.

NRC. 2001. Nutrient Requirements for Dairy Cattle. 7th rev. ed. ed. National Academy Press, Washington, DC.

Overton, T. R., and M. R. Waldron. 2004. Nutritional management of transition dairy cows: strategies to optimize metabolic health. J. Dairy Sci. 87(E Suppl.):E105-E119.

Park, C. S., G. M. Erickson, Y. J. Choi, and G. D. Marx. 1987. Effect of compensatory growth on regulation of growth and lactation: Response of dairy heifers to a stair-step growth pattern. J. Anim. Sci. 64:1751-1758.

Rabelo, E., R. L. Rezende, S. J. Bertics, and R. R. Grummer. 2003 Effects of transition diets varying in dietary energy density on lactation performance and ruminal parameters of dairy cows. J. Dairy Sci. 86:916-925.

Rabelo, E., R. L. Rezende, S. J. Bertics, and R. R. Grummer. 2005. Effects of pre- and postfresh transition diets varying in dietary energy density on metabolic status of periparturient dairy cows. J. Dairy Sci. 88:4375-4383.

Rukkwamsuk, T., T. Wensing, and M. J. H. Geelen. 1998. Effect of overfeeding during the dry period on regulation of adipose tissue metabolism in dairy cows during the periparturient period. J. Dairy Sci. 81:2904-2911.

Rukkwamsuk, T., T. Wensing, and M. J. H. Geelen. 1999. Effect of overfeeding during the dry period on the rate of esterification in adipose tissue of dairy cows during the periparturient period. J. Dairy Sci. 82:1164-1169.

VandeHaar, M. J., G. Yousif, B. K. Sharma, T. H. Herdt, R. S. Emery, M. S. Allen, and J. S. Liesman. 1999. Effect of energy and protein density of prepartum diets on fat and protein metabolism of dairy cattle in the periparturient period. J. Dairy Sci. 82:1282-1295.

Waltner, S. S., J. P. McNamara, and J. K. Hillers. 1993. Relationships of body condition score to production variables in high producing Holstein dairy cattle. J. Dairy Sci. 76:3410-3419.

Wildman, E. E., G. M. Jones, P. E. Wagner, R. L. Boman, H. F. Troutt, and T. N. Lesch. 1982. A dairy cow body condition scoring system and its relationship to selected production characteristics. J. Dairy Sci. 65:495-501.

Winkelman, L. A., T. H. Elsasser, and C. K. Reynolds. 2008. Limitfeeding a high-energy diet to meet energy requirements in the dry period alters plasma metabolite concentrations but does not affect intake or milk production in early lactation. J. Dairy Sci. 91:1067-1079. 